\title{
Carbonyls and Nonmethane Hydrocarbons at Rural European Sites from the Mediterranean to the Arctic
}

\author{
SVERRE SOLBERG, CHRISTIAN DYE and NORBERT SCHMIDBAUER \\ Norwegian Institute for Air Research, Instituttveien 18, N-2007 Kjeller, Norway
}

\begin{abstract}
ALEX HERZOG and ROBERT GEHRIG
Swiss Federal Lab. for Materials Testing and Research, Überiandstr. 129, CH-8600 Dübendorf, Switzerland
\end{abstract}

(Received: 16 January 1996; in final form: 20 May 1996)

\begin{abstract}
Results of regular measurements during 1992-1995 of hydrocarbons and carbonyl compounds for a number of rural European monitoring sites are presented. The measurements are part of the EMEP programme for VOC measurements in Europe. In addition, several years of regular measurements are included from the Norwegian stations Birkenes at the south coast, and Zeppelin Mountain on Spitsbergen in the Arctic. The sampling frequency has been about twice per week throughout the years, implying that a substantial amount of measurement data are available. Almost all the chemical analyses have been performed by one laboratory, the EMEP Chemical Co-ordinating Centre located at NILU, which avoids problems of intercomparison and intercalibration among different laboratories. For the measured concentrations both seasonal and geographical variations are shown and discussed. The diurnal cycles of the hydrocarbon concentrations were studied in detail at one site, where the grab samples by EMEP where compared with a parallel continuous sampler, operated by EMPA, Switzerland. Hydrocarbons linked to natural gas and fuel evaporation become well mixed into the Arctic in the winter, whereas combustion products show a latitudinal gradient. The sum of oxygenated species constitutes about $5-15 \%$ of the sum of $\mathrm{C}_{2}-\mathrm{C}_{5}$ hydrocarbons in winter. In summer they are almost equal in magnitude, consistent with an increasing oxidation of hydrocarbons.
\end{abstract}

Key words: hydrocarbons, carbonyl compounds, measurements, European concentrations, rural sites.

\section{Introduction}

Volatile organic compounds (VOC) play a central role in many aspects of tropospheric chemistry. Anthropogenic emissions of hydrocarbons (R-H) in combination with nitrogen oxides $\left(\mathrm{NO}_{x}\right)$ lead to the formation of ozone, PAN and other oxidants when there is sufficient UV-radiation. Moreover, through the hydrocarbons' primary reaction with the $\mathrm{OH}$ radical, and through the subsequent degradation of the organic compounds, the concentration of the $\mathrm{OH}$ radical will be altered, which in turn causes a general perturbation of the tropospheric chemistry (Isaksen, 1988).

A wide range of aldehydes ( $\mathrm{R}-\mathrm{CHO})$ and ketones (R-CO-R) are formed when the primary hydrocarbons are decomposed in the troposphere. The carbonyl compounds (aldehydes and ketones) are themselves successively broken down by reaction with $\mathrm{OH}$ and by photodissociation to simpler carbonyls, before they form $\mathrm{CO}$ and ultimately $\mathrm{CO}_{2}$. If the $\mathrm{NO}_{x}$ concentration exceeds a critical value of a few 
10's of ppt, ozone molecules are formed during the degradation process (Crutzen, 1988). The concentration and distribution of carbonyl compounds are therefore, to some extent, indications of the previous oxidation of hydrocarbons in the air mass, and have been proposed suitable for validation of photochemical models (Chatfield et al., 1987).

Simultaneous measurements of hydrocarbons and carbonyl compounds are a particularly powerful tool, because the relative distributions between the primary pollutants and the secondary formed products give a picture of the photochemical history of the air mass. The interpretation is, however, complicated in many ways. Some of the carbonyl compounds are themselves emitted in considerable amounts, and the carbonyls may be so short lived that they are decomposed during the transport.

Another application of VOC measurements is to validate emission inventories. In this context, measurements of hydrocarbons alone are limited by the fact that by the time of measurement many of the emitted hydrocarbons may have reacted, and a large share of the emitted components may have been converted to aldehydes and ketones. The sum of hydrocarbons and carbonyl compounds is therefore a more conservative quantity, although a significant fraction of the carbonyls also may have been lost.

Based on the recommendations from the EMEP (Co-operative programme for monitoring and evaluation of the long range transmission of air pollutants in Europe) Workshop on Measurements of Hydrocarbons/VOC in 1989, a pilot programme on light hydrocarbons, aldehydes and ketones was initiated within EMEP. This programme aimed at collecting VOC data as a support to the ongoing modelling of photochemical oxidants. The hydrocarbon measurements within EMEP started in the autumn of 1992, while the analysis of carbonyls were initiated during spring 1993. The measurements have previously been presented in EMEP reports (Solberg et al., 1993; 1994; 1995a).

In the EUROTRAC sub project TOR (Tropospheric Ozone Research) hydrocarbons have been measured at an increasing number of sites since 1987. The co-operation between EMEP and the TOR project has allowed an exchange of measurement data. Some results from the combined EMEP and TOR hydrocarbon measurements have been published by Lindskog et al. (1995).

This paper presents the EMEP VOC measurements from the start until the beginning of 1995, financed by EMEP, as well as the VOC measurements at the two Norwegian TOR stations, Birkenes at the south coast of Norway and Zeppelin Mountain on Spitsbergen in the Arctic, financed by NILU (Norwegian Institute for Air Research). Measurements of hydrocarbons at the latter sites have previously been presented by Hov et al. (1984, 1989, 1990, 1991, 1995), Isaksen et al. (1985), Hov and Schmidbauer (1992) and Solberg et al. (1995b). An important objective with this paper is to provide modellers with applicable measurement data of VOC concentrations in Europe. In addition the representativity of the grab samples is 


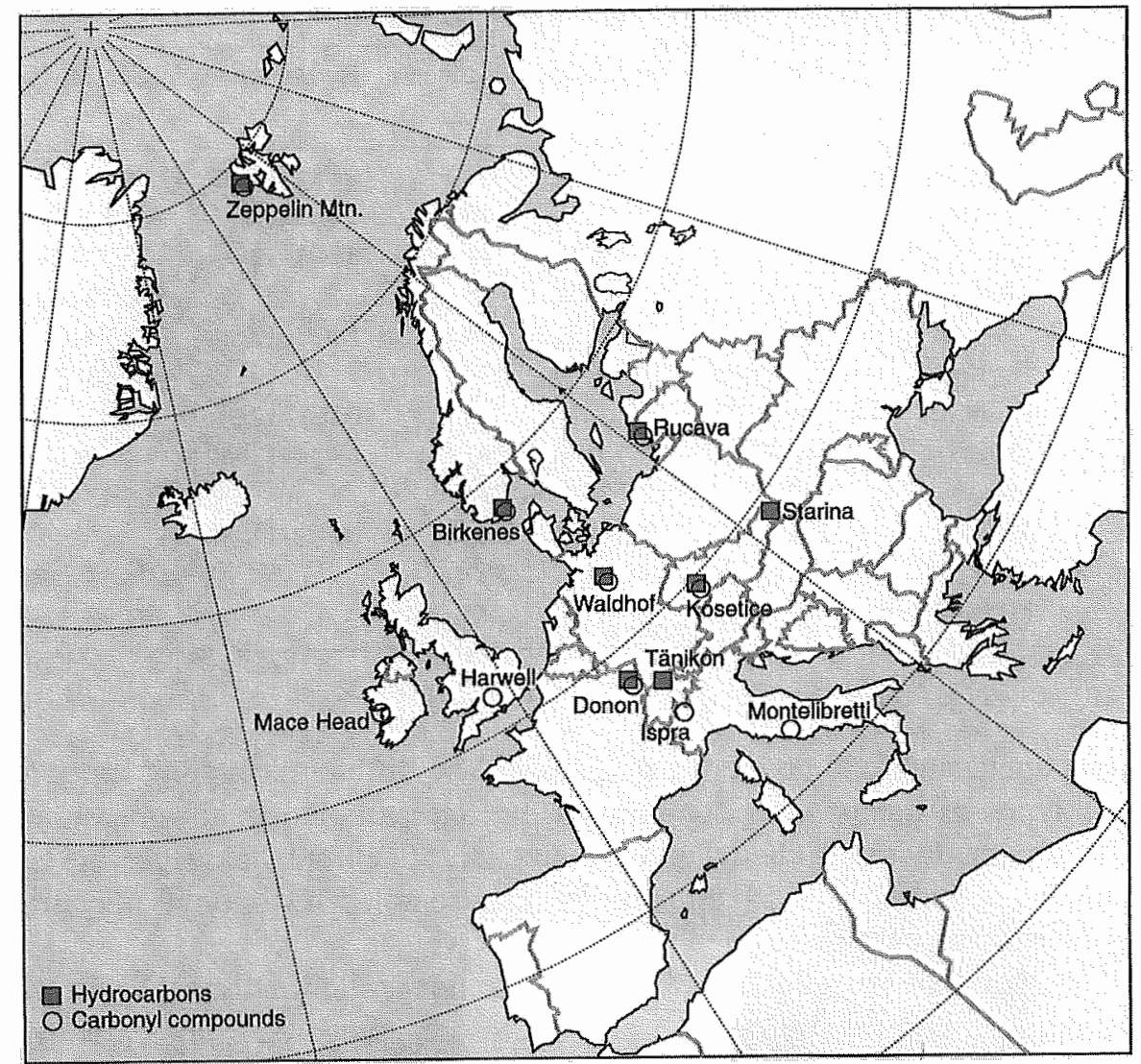

Figure 1. Map showing the location of the EMEP VOC measuring stations and the Norwegian TOR sites (Birkenes and the Zeppelin Mountain). The symbols mark what type of compounds are measured at the different sites.

discussed by comparison with continuous measurements, and the geographical and temporal variations are presented.

\section{Instrumentation, Sampling Procedures and Site Locations}

\subsection{SAMPLING TIMES AND SITES}

Figure 1 shows the location of the EMEP VOC stations presented here, as well as the two Norwegian TOR sites. The different symbols mark the types of measurements performed at the different locations. Table I gives the names of the stations, geographical coordinates, altitudes and the type of measurements.

The hydrocarbons and carbonyl compounds are normally sampled on the same days twice per week, mostly on Mondays and Thursdays. The canisters for spot sampling of hydrocarbons are normally filled about noon during a time of 10-20 min. (as described in more detail below), while the 8 hours sampling of carbonyl 
Table I. The measurement data which this work is based on

\begin{tabular}{lrrrrr}
\hline Station & Latitude & Longitude & $\begin{array}{c}\text { Altitude } \\
\text { (m a.s.l.) }\end{array}$ & Hydrocarbons & Carbonyls \\
& & & & \\
\hline Zeppelin Mtn. & $78^{\circ} 55^{\prime} \mathrm{N}$ & $11^{\circ} 54^{\prime} \mathrm{E}$ & 474 & $09 / 89-12 / 94$ & $04 / 94-09 / 94$ \\
Birkenes & $58^{\circ} 23^{\prime} \mathrm{N}$ & $8^{\circ} 15^{\prime} \mathrm{E}$ & 116 & $01 / 88-12 / 94$ & $03 / 93-05 / 95$ \\
Rucava & $56^{\circ} 13^{\prime} \mathrm{N}$ & $21^{\circ} 13^{\prime} \mathrm{E}$ & 18 & $09 / 92-12 / 94$ & $05 / 93-06 / 95$ \\
Mace Head & $53^{\circ} 10^{\prime} \mathrm{N}$ & $9^{\circ} 30^{\prime} \mathrm{W}$ & 15 & & $10 / 93-04 / 95$ \\
Waldhof & $52^{\circ} 48^{\prime} \mathrm{N}$ & $10^{\circ} 45^{\prime} \mathrm{E}$ & 74 & $10 / 92-12 / 94$ & $05 / 93-04 / 95$ \\
Harwell & $51^{\circ} 25^{\prime} \mathrm{N}$ & $1^{\circ} 19^{\prime} \mathrm{W}$ & 137 & & $08 / 93-06 / 94$ \\
Kosetice & $49^{\circ} 35^{\prime} \mathrm{N}$ & $15^{\circ} 05^{\prime} \mathrm{E}$ & 633 & $08 / 92-12 / 94$ & $04 / 93-04 / 95$ \\
Starina & $49^{\circ} 03^{\prime} \mathrm{N}$ & $22^{\circ} 16^{\prime} \mathrm{E}$ & 345 & $09 / 94-12 / 94$ & \\
Donon & $48^{\circ} 30^{\prime} \mathrm{N}$ & $7^{\circ} 08^{\prime} \mathrm{E}$ & 775 & & $06 / 93-04 / 95$ \\
Tänikon & $47^{\circ} 29^{\prime} \mathrm{N}$ & $8^{\circ} 54^{\prime} \mathrm{E}$ & 540 & $09 / 92-12 / 94$ & \\
Ispra & $45^{\circ} 48^{\prime} \mathrm{N}$ & $8^{\circ} 38^{\prime} \mathrm{E}$ & 209 & & $04 / 93-04 / 95$ \\
Montelibretti & $42^{\circ} 06^{\prime} \mathrm{N}$ & $12^{\circ} 38^{\prime} \mathrm{E}$ & 48 & & $07 / 93-02 / 95$ \\
\hline
\end{tabular}

compounds are done centred around noon. The different sampling times for the two types of components complicates the interpretation of the measurements. During situations with changing wind directions, like frontal passages, the canister samples of hydrocarbons and the DNPH tube samples of carbonyls may originate from different air masses.

Furthermore, if the hydrocarbon concentrations follow a diurnal cycle, the spot sampling at noon will produce a bias in the data compared to the carbonyl data. However, at rural sites, local anthropogenic emissions should be small and as the dry deposition of hydrocarbons is negligible, one should not expect a large diurnal cycle. It is therefore of interest to investigate how representative the spot sampling of hydrocarbons at noon are. The representativity depends both on the site location, time of year etc., and is therefore not easy to estimate on an average basis. Section 3 presents a comparison between the spot samples from Tänikon and the continuous measurements performed at the same location by EMPA.

Particularly in central Europe, rural sites are on occasions exposed both to advection of polluted air masses from the nearest cities, and episodically contaminated by nearby emissions. Table II gives an idea of the influence of regional anthropogenic sources at the different sites. This table shows the average and 95 percentile $\mathrm{NO}_{2}$ concentration observed during December 1992 to February 1993 at sites with daily filter samples of nitrogen and sulphur compounds in the EMEP monitoring network (Lövblad et al., 1995). Also given is the $50 \times 50 \mathrm{~km}^{2}$ and $150 \times 150 \mathrm{~km}^{2}$ grid square emission flux of $\mathrm{NO}_{x}$, based on recent estimates (Berge et al., 1995). There are large differences in the observed $\mathrm{NO}_{2}$ concentrations with Birkenes and Rucava showing the smallest anthropogenic influence and Ispra the highest. Birkenes, Rucava, Mace Head, Waldhof, Kosetice, Starina and Donon all have fairly low emission rates in the $50 \times 50 \mathrm{~km}^{2}$ grid square, whereas several of 
Table II. Average ( $\overline{\mathrm{C}}$ winter) and 95 percentile $\left(\mathrm{P}_{95}\right.$, winter) of daily measured $\mathrm{NO}_{2}$ concentrations for December 1992-February 1993, as well as the $50 \times 50 \mathrm{~km}^{2}\left(\mathrm{E}_{\mathrm{NO}_{x}}, 50\right)$ and $150 \times 150 \mathrm{~km}^{2}\left(\mathrm{E}_{\mathrm{NO}_{x}}, 150\right)$ grid square emission flux of $\mathrm{NO}_{x}$

\begin{tabular}{lcccc}
\hline & $\begin{array}{l}\overline{\mathrm{C}} \text { winter } \\
\left(\mu \mathrm{g} \mathrm{N} \mathrm{m}^{-3}\right)\end{array}$ & $\begin{array}{l}\mathrm{P}_{95}, \text { winter } \\
\left(\mu \mathrm{g} \mathrm{N} \mathrm{m}^{-3}\right)\end{array}$ & $\begin{array}{l}\mathrm{E}_{\mathrm{NO}_{x}, 50} \\
\left(1000 \text { tonnes } \mathrm{y}^{-1}\right)\end{array}$ & $\begin{array}{l}\mathrm{E}_{\mathrm{NO}_{x}, 150} \\
\left(1000 \text { tonnes } \mathrm{y}^{-1}\right)\end{array}$ \\
\hline Birkenes & 0.84 & 2.61 & 1.1 & 13 \\
Rucava & 1.62 & 3.82 & 1.3 & 12 \\
Mace Head & & & 0.1 & 42 \\
Waldhof & 5.31 & 11.70 & 3.6 & 123 \\
Harwell & & & 44.2 & 286 \\
Kosetice & 3.32 & 10.18 & 1.9 & 74 \\
Starina & & & 4.2 & 60 \\
Donon & & & 3.3 & 94 \\
Tänikon & 7.34 & 12.60 & 16.8 & 119 \\
Ispra & 12.51 & 19.90 & 29.5 & 181 \\
Montelibretti & & & 10.8 & 173 \\
\hline
\end{tabular}

these sites are located in areas with high emission fluxes in the $150 \times 150 \mathrm{~km}^{2}$ grid square. This indicates that the sites are not located in the vicinity of major source areas, but may be situated in high emission regions. Montelibretti, Tänikon, Ispra, and Harwell are exceptions to this. They are all located in $50 \times 50 \mathrm{~km}^{2}$ grid squares with high emission rates reflecting more densely populated areas, and are possibly more subject to fresh anthropogenic plumes.

\subsection{ANALYSIS OF HYDROCARBONS}

Air samples are collected manually by filling evacuated electropolished, stainless steel canisters of $0.8 \mathrm{l}$ volume, during a time of 10-20 min. The bottles are then shipped to the laboratory, and the chemical analyses normally take place within a week after the time of sampling. Most of the hydrocarbon measurements in EMEP have so far been analysed by the Chemical Co-ordinating Centre (CCC) located at NILU. Samples from September to December 1994 from Donon, Ispra and Montelibretti were analysed by the JRC-Ispra in Italy, but are not presented here. The laboratory at NILU was accredited according to EN 45001 in September 1993.

The air samples are now analysed for $\mathrm{C}_{2}-\mathrm{C}_{7}$ alkanes, $\mathrm{C}_{2}-\mathrm{C}_{5}$ alkenes, as well as aromatics (benzene, toluene and xylenes), isoprene and acetylene. Until 1991 (before the start of the EMEP VOC programme), only $\mathrm{C}_{2}-\mathrm{C}_{5}$ compounds were analysed at the TOR sites Birkenes and the Zeppelin Mountain. This paper mostly presents the $\mathrm{C}_{2}-\mathrm{C}_{5}$ compounds. Note that due to problems in integrating the chromatograms for propene after July 1993 for Birkenes and the Zeppelin Mountain, no propene data have been obtained after this time for these two sites. Note also that 
due to local contamination, the hydrocarbon samples from Rucava in the period June-November 1994 had to be discarded.

The laboratory analysis at NILU is done by gas chromatography with flame ionisation detection by an automated Chrompack VOC-AIR instrument. A detailed documentation of the instrumentation and analysis procedure is given in EMEP/CCC (1995), and by Schmidbauer and Oehme (1986). A NIST certified standard gas mixture containing $10 \mathrm{ppb} n$-butane and benzene is used every day to calibrate the instrument. A response factor calculated for $1 \mathrm{ppbC}$ together with the carbon number is then applied to all hydrocarbons. Except for acetylene, this approach has been shown to be valid for most hydrocarbons. The acetylene concentrations reported by NILU in intercalibration exercises are, however, often in the upper range, which could indicate that the applied response factor derived from $n$-butane may be too low for acetylene. The cleaning of the canisters, checking of their blankvalues, sample stability studies and a record of every canister are very important parts of the analysis. There are no corrections made for any possible deviations of the detector response due to differences in the molecular structure. In the EC intercomparison reported by De Saeger and Tsani-Bazaca (1992) the accuracy of the results from NILU compared very well with the gravimetric determination by Partridge (1992). An intercomparison of analytical methods for VOC organised within EMEP in 1993 revealed that most of the labs analysed a wide range of hydrocarbons within an accuracy of $\pm 10-15 \%$ (Romero, 1995).

In addition to the JRC-Ispra, the laboratories at the hydrometeorological institutes in the Czech Republic and in Slovakia have started their own analyses of hydrocarbons. Both institutes participated in an exercise where the same canister samples were first analysed by their own laboratories, and then shipped to the lab at NILU and re-analysed. After a certain time of intercalibration and exchange of standards to establish response factors for their instruments, very encouraging results were obtained. Figure 2 shows the comparison of ethene analysed by NILU and the Slovak Hydrometeorological Institute. Ethene is often claimed not to be stable in canister samples. The agreement between the results is excellent and the time series correlate very well. There is no evidence for problems of sample stability or integrity over long periods of storage. As the ethene concentration at Starina mostly was above $500 \mathrm{ppt}$, these observations do not, however, contradict the hypothesis that ethene contamination in steel canisters may be a problem at low concentrations. Furthermore, the good agreement between the two labs' analyses is only indicative of the stability between the times of these analyses. Possible processes occurring in the first few hours after sampling would not be detected by this type of comparison.

\subsection{CONTINUOUS SAMPLING AND ANALYSIS OF HYDROCARBONS}

Tänikon, located in the north-eastern part of Switzerland, was established as an EMEP VOC site in August 1992 and is also part of the Swiss federal air pollution 


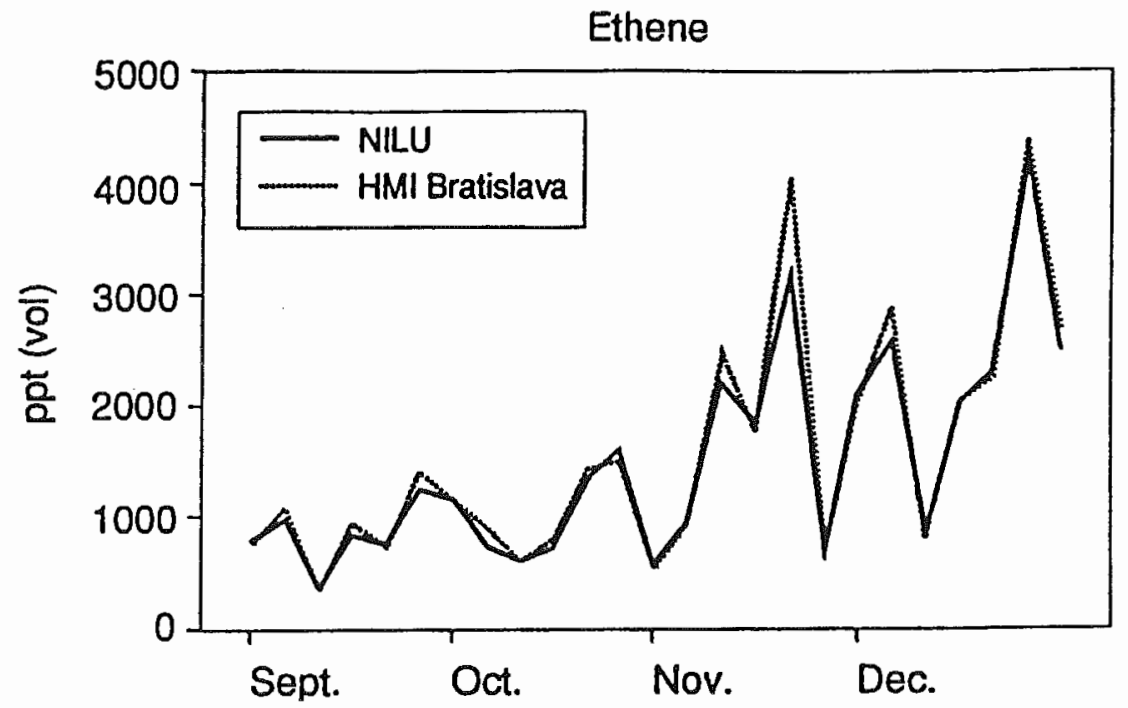

Figure 2. Ethene at Starina, Slovakia, as analysed from the same canister samples by two laboratories during four months in 1994. The labs were NILU and the Hydrometeorological Institute, Slovakia.

network (NABEL). Since July 1994 hydrocarbons have been measured continuously by EMPA (Swiss Federal Laboratories for Material Testing and Research). The fully automated measurement system for hydrocarbons is based on a Varian 3400 gas chromatograph (Varian Inc., CA, USA), equipped with a flame ionisation detector (FID) and a Varian SPT system (sample preconcentration trap). Varian software is used for data collection and peak integration. The spectrum of the analysed $\mathrm{C}_{2}-\mathrm{C}_{8}$ compounds corresponds to that of the EMEP VOC programme with the exception of ethane and n-heptane.

The ambient air is aspirated inside the station cabin from a well ventilated glass manifold $\left(40 \mathrm{~m}^{3} \mathrm{~h}^{-1}\right)$ by a mass flow controller (Bronkhorst High-Tech BV, Ruurlo, The Netherlands) and a pump. Sampling is performed 12 times a day with a sampling duration of $30 \mathrm{~min}$ at a flow rate of $20 \mathrm{ml} \mathrm{min}^{-1}$. Each analysis cycle consists of the following steps: At the initial stage, the stainless steel trap (2 $\mathrm{mm}$ i.d., $3 \mathrm{~mm}$ o.d., $30 \mathrm{~cm}$ long), packed with two adsorbents $(29 \mathrm{~cm}$ HayeSep D 60/80 mesh and $1 \mathrm{~cm}$ activated charcoal $60 / 80$ mesh) is precooled with liquid $\mathrm{CO}_{2}$ to $-45^{\circ} \mathrm{C}$. Then, by activating two Valco valves (type -WT; 6-port and 10port,) dehydrated ambient air passes through the trap (Valco Instruments Co. Inc., Houston, U.S.A.). Still at $-45^{\circ} \mathrm{C}$, the trap is purged with carrier gas $\left(99.999 \% \mathrm{~N}_{2}\right.$ cleaned with activated charcoal and molecular sieve filters) for $0.5 \mathrm{~min}$ at a rate of $7.5 \mathrm{ml} \mathrm{min}{ }^{-1}$ to remove residual oxygen. Then the trap is isolated from the gas stream and rapidly heated to $145{ }^{\circ} \mathrm{C}$ (conduction heat) and held for $0.9 \mathrm{~min}$ to desorbe the components. Without further focusing the sample is then injected into the analytical column (PLOT, $\mathrm{Al}_{2} \mathrm{O}_{3} / \mathrm{KCl}, 50 \mathrm{~m}$ long and $0.53 \mathrm{~mm}$ i.d., Chrompack, 
Middelburg, The Netherlands) by flushing carrier gas through the trap at a rate of $7.5 \mathrm{ml} \mathrm{min}{ }^{-1}$. For the purpose of trap cleaning the gas flow in the trap is maintained until the end of the analysis. The oven temperature program is as follows: $5 \mathrm{~min}$ at $40^{\circ} \mathrm{C}$ then $190^{\circ} \mathrm{C}$ with $4{ }^{\circ} \mathrm{C} \mathrm{min}{ }^{-1}$, held $10 \mathrm{~min}, 200^{\circ} \mathrm{C}$ with $15^{\circ} \mathrm{C} \mathrm{min}^{-1}$, held $15 \mathrm{~min}$. Prior to analytical preconcentration humidity is selectively removed from the sample air by passing it through a nafion dryer, model MD-125-48(S) (Perma Pure Products, Farmingdale, N.J.). To prevent excessive moisture build-up and memory effects in the dryer, an automated clean-up procedure that involves periodically heating the dryer $\left(100^{\circ} \mathrm{C}\right)$ while being purged with zero air is installed (Pleil and Oliver, 1987).

For calibration two Scott Environmental Technology, Inc. pressurised cylinders containing a mixture of $15 \mathrm{ppmv}$ of the following compounds in nitrogen are used as working standards: Cylinder 1: all $\mathrm{n}$-alkanes up to $\mathrm{n}$-hexane, cylinder 2: $i$-butane, 2,2-dimethylpropane, $i$-pentane, 2,2-dimethylbutane, 2-, and 3-methylpentane. For calibration runs, appropriate amounts of the standards are dosed to humidified zero air with a gastight syringe to reach a nominal concentration of about $1-1.5 \mathrm{ppb}$. The results are taken as a basis for calculation of carbon-number-response. The estimated error (standard, dilution) is about $20 \%$.

The EMPA laboratory participated in two intercalibration exercises in 1994. For the compounds discussed in this paper the results of the EMEP intercalibration (Romero, 1995) are $-3 \%$ for propane and $+13 \%$ for ethene compared to NILU, whereas the results of the second EU intercalibration reported by De Saeger (1994) agreed very well with the gravimetric standard.

\subsection{ANALYSIS OF CARBONYL COMPOUNDS}

The sampling of carbonyl compounds is done by drawing air through a cartridge which contains silica coated with 2,4-dinitrophenylhydrazine (2,4-DNPH) packed in a polyethylene tube. The aldehydes and ketones react with the acidified 2,4DNPH to form the corresponding hydrazones. The sampling time is about 8 hours, and the total air sample volume is 750 litres. The tubes are then shipped to the laboratory where the subsequent analyses of the hydrazones are performed. All the chemical analyses of carbonyl compounds have been done by the CCC of EMEP at NILU.

The cartridges are eluated with acetonitrile, and the sample extract is analysed by reversed phase high-performance liquid chromatography by UV detection, using a Hewlett Packard 1050 modular system equipped with a diode array detector. The detection limits of the carbonyl compounds are in the range of $0.01-0.05 \mu \mathrm{g} \mathrm{m}^{-3}$. This method is a modification of the method presented by Slemr (1991), and it is described in detail in EMEP/CCC (1995).

Parallel sampling, using two samplers simultaneously, was performed at Birkenes twice a week for a period of 8 months. The results for formaldehyde, acetaldehyde and acetone are shown in Figure 3. In general the two time series agree very well 
with a few exceptions. At day 100 in 1995 there was a deviation of about $35 \%$ for all three compounds. This was most likely caused by technical problems in volume recording. Apart from this the measured acetaldehyde concentrations also show a marked deviation at day numbers 26,30 and 37 in 1995. At the moment the reason for these discrepancies is not clear. A possible explanation could be the formation of syn- and anti-isomers of the acetaldehyde hydrazone, which makes it more difficult to integrate the chromatograms.

The analytical method was capable of identifying a wide spectrum of individual compounds, but the number of compounds actually detected was often limited by concentrations dropping below the detection limit. The carbonyl compounds reported to the EMEP VOC database include aldehydes up to $\mathrm{C}_{6}$ (hexanal), a number of ketones including methylethylketone and methylvinylketone, as well as aromatic carbonyls (benzcarbaldehydes etc.). For many of the higher order carbonyls the measurement data are, however, rather sparse at many of the sites, because the compounds were not detectable. Note that the samples of carbonyls from Rucava in the period from mid September 1993 to the end of the year had to be discarded due to technical problems.

A standard gas meter was used for the volume determination, with no correction for possible changes in pressure or temperature inside the instrumentation. The pressure will not change, but there may be a slight heating of the air causing a slight change in the volume. The carbonyl concentrations are initially reported as $\mu \mathrm{g} \mathrm{m}^{-3}$, and the uncertainty in the volume determination thus introduces an uncertainty in the reported gas concentrations. This uncertainty will, however, be at most $10 \%$. This is less than the overall uncertainty of the measurement method, which is $15 \%$ according to the accreditation. In this paper all carbonyl concentrations were transformed from $\mu \mathrm{g} \mathrm{m}^{-3}$ to volume mixing ratios (ppt or $\mathrm{ppb}$ ) by assuming a temperature of $288 \mathrm{~K}$ and a pressure of $1013 \mathrm{hPa}$. This will not raise the uncertainty of the concentration values significantly, and an uncertainty of $15 \%$ is still valid.

\section{Comparison between Grab Sampling and Continuous Measurements of Hydrocarbons}

The total data set of the continuous hydrocarbon measurements comprises a spectrum of 19 analysed $C_{2}-C_{8}$ compounds or compound groups for the time period between 1 August and 31 December 1994. Seven compounds with different sources and reactivities were selected for the comparison with the grab samples: Ethene, propane, $i$-butane, $i$-pentane, $n$-pentane, benzene and toluene. To investigate seasonal differences, the data set was divided into a summer period (1 August to 15 September) and a winter period (16 September to 31 December).

Every single measurement consists of a half-hourly value, sampled every two hours between $\mathrm{hh}: 30$ and $[\mathrm{hh}+1]: 00$ exactly, except during the summer season when the starting time could vary \pm 20 min or even shift for a whole hour. The 

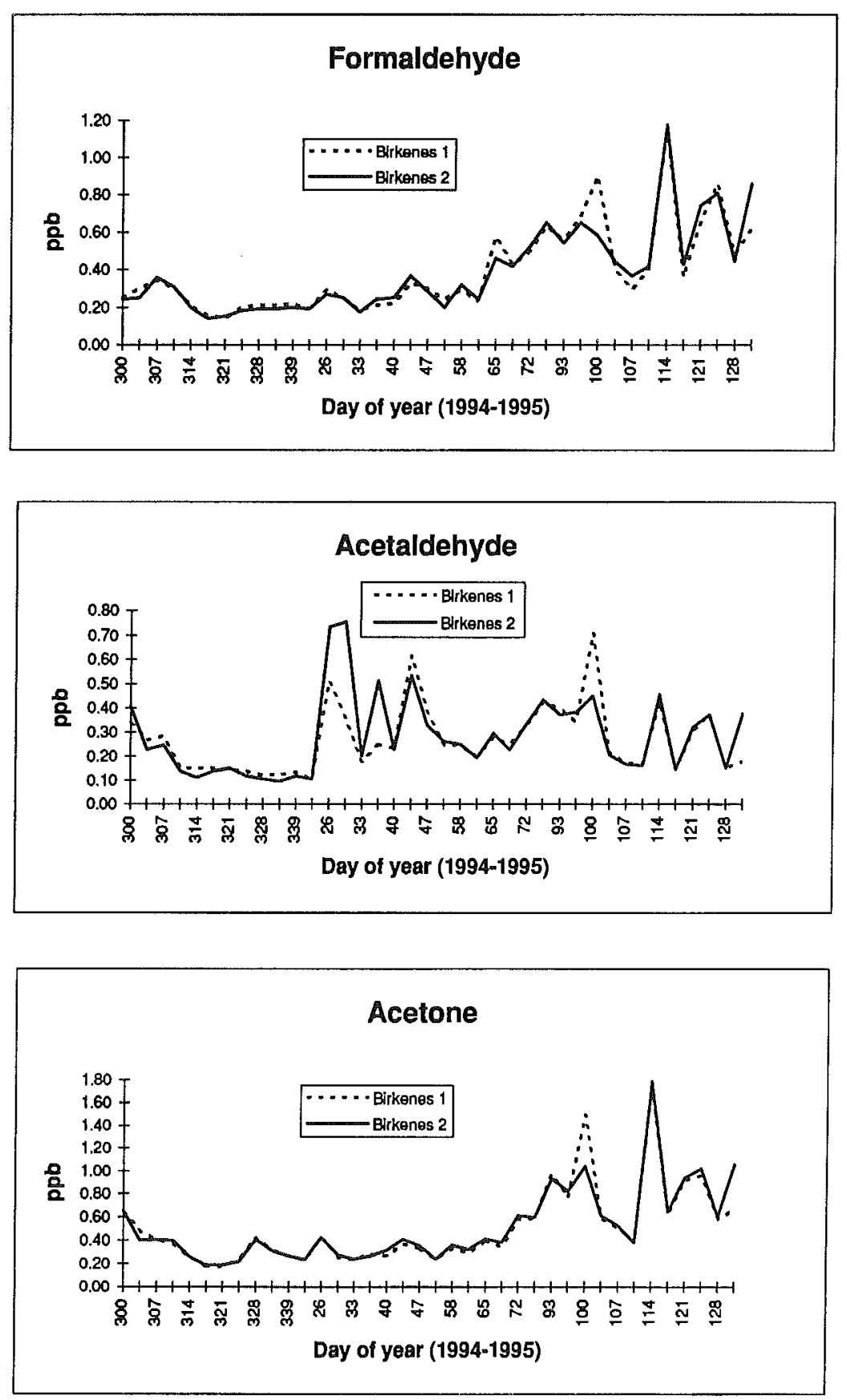

Figure 3. Time series from two parallel measurements of carbonyls at Birkenes in an eight months period during autumn 1994 to spring 1995. The x-axis gives the day of year in 1994 and 1995. All values are in $\mathrm{ppb}$. 
Table III. Comparison of grab samples (NILU) and continuous measurements (EMPA) sampled in parallel: Mean values $\bar{x}_{\text {grab }}, \bar{x}_{\text {cont }}$, linear regression $x_{\text {cont }}=$ $a \cdot x_{\text {grab }}+b$, correlation coefficient $r$, standard deviation of the slope $s_{a}$, standard deviation of the intercept $s_{b}$ and number of data pairs $n$

\begin{tabular}{|c|c|c|c|c|c|c|c|c|}
\hline & $\begin{array}{l}\bar{x}_{\text {grab }} \\
\text { [ppt] }\end{array}$ & $\begin{array}{l}\bar{x}_{\text {cont }} \\
{[\mathrm{ppt}]}\end{array}$ & $a$ & $\begin{array}{l}b \\
{[\mathrm{ppt}]}\end{array}$ & $s_{a}$ & $\begin{array}{l}s_{b} \\
{[\mathrm{ppt}]}\end{array}$ & $r$ & $n$ \\
\hline Ethene & 1460 & 1780 & 1.139 & 110 & 0.132 & 244 & 0.907 & 18 \\
\hline Propane & 770 & 780 & 0.963 & 40 & 0.079 & 77 & 0.952 & 17 \\
\hline$i$-Butane & 390 & 380 & 0.860 & 40 & 0.081 & 41 & 0.940 & 17 \\
\hline$i$-Pentane & 900 & 880 & 0.952 & 20 & 0.122 & 134 & 0.895 & 17 \\
\hline$n$-Pentane & 390 & 340 & 0.923 & -20 & 0.060 & 29 & 0.970 & 17 \\
\hline Benzene & 480 & 340 & 1.004 & -140 & 0.107 & 57 & 0.921 & 18 \\
\hline Toluene & 710 & 690 & 0.933 & 30 & 0.071 & 59 & 0.957 & 18 \\
\hline
\end{tabular}

measured concentrations were attributed to the full hour in which the sampling took place. To ease the discussion of diurnal cycles, an additional data set consisting of hourly values was prepared, in which the missing hour between two consecutive measurements was interpolated. Gaps of more than two hours were not interpolated but treated as missing values. Most data gaps were caused by instrumental failure or reconstruction problems of the adsorption tube. Totally 861-907 measurements exist for each species.

Differences in concentrations between the continuous measurements and the grab sampling could either be due to different analytical methods or due to the different time periods covered by the two methods. In Section 3.1 below we discuss the differences which could be ascribed to the different analytical methods, by comparing the noon values from the continuous measurements with the grab samples (which are all performed around noon). Then, in Section 3.2, diurnal cycles in the concentrations are discussed to elucidate the differences between noon concentrations and concentrations at other times of the day.

\subsection{COMPARISON OF THE NOON CONCENTRATIONS OBTAINED BY THE CONTINUOUS MEASUREMENTS AND THE GRAB SAMPLING}

As the sampling by the two methods were not performed exactly simultaneously, the values closest in time, or in some cases the mean value of the two measurements before and after the grab sampling, were used for the comparison. The results of the comparison are presented in the form of a linear regression analysis in Table III.

For propane, $i$-butane, $i$-pentane, $n$-pentane and toluene the agreement of the mean noon values between the grab samples and the continuous measurements was very good. The regression analysis shows that neither the slopes differ significantly from 1 nor the intercepts from 0 . However, the standard deviations are in some cases considerable. One explanation for this could be, that the sampling for the two 
compared methods was not covering exactly the same time periods as mentioned above.

Higher differences in the mean noon concentrations of benzene and ethene were obtained between the two methods, indicating systematic differences in the analytical procedure, though only the intercept of benzene was significantly different from 0 (on the $95 \%$ confidence level). For ethene similar differences between NILU and EMPA were already observed in the EMEP intercalibration (Romero, 1995).

\subsection{DIURNAL CYCLES IN HYDROCARBON CONCENTRATIONS}

The continuous measurements were used to calculate the diurnal cycles in the components. To suppress an undue influence of days with high concentrations, relative diurnal cycles were calculated by dividing every single observation by the average concentration of that day. Furthermore, the observations were classified into two groups of data, according to the daily average wind speed at the station: Below $1 \mathrm{~m} \mathrm{~s}^{-1}$ and above $1.8 \mathrm{~m} \mathrm{~s}^{-1}$, approximately equal to the 30 and 70 percentile of the wind speed distribution, respectively. At low wind speeds the influence from local sources should be visible, whereas at high wind speeds the more regional characteristics should be reflected.

The resulting average relative diurnal cycles are shown in Figure 4. Measurements sampled during the low wind speeds show an influence from local traffic with peak emissions in the rush hours. The diurnal cycle of propane is an exception to this, indicating a different source for this compound. The diurnal cycles of the components during the higher wind speeds are less pronounceed, consistent with a more thorough mixing which reduces the local influence. The diurnal cycles at days with high wind speeds reflect the influence from different regional sources at different distances, occasionally superimposed by local events. This analysis shows that the measuring site at Tänikon is exposed to local traffic emissions, but the grab sampling around noon seems to be a well chosen time due to the absence of traffic peak emissions at this time of the day.

The relationship between the noon values and the daily means, using the continuous measurements only, was investigated by linear regression analysis, and the results are given in Table IV. All slopes in Table IV are less than 1, implying that the noon values were lower than the daily means, consistent with the calculated diurnal cycles in Figure 4. The correlation coefficients for $i$-butane, $i$-pentane and $n$-pentane are relatively low, and, as shown in Figure 5, they are affected by three encircled events when the noon values were much higher than the daily means. Rejecting these values improved the correlation significantly, as given in Table IV. Butanes and pentanes are related to fuel evaporation and spillage (Harley $e t$ al., 1992) in contrast to propane. 


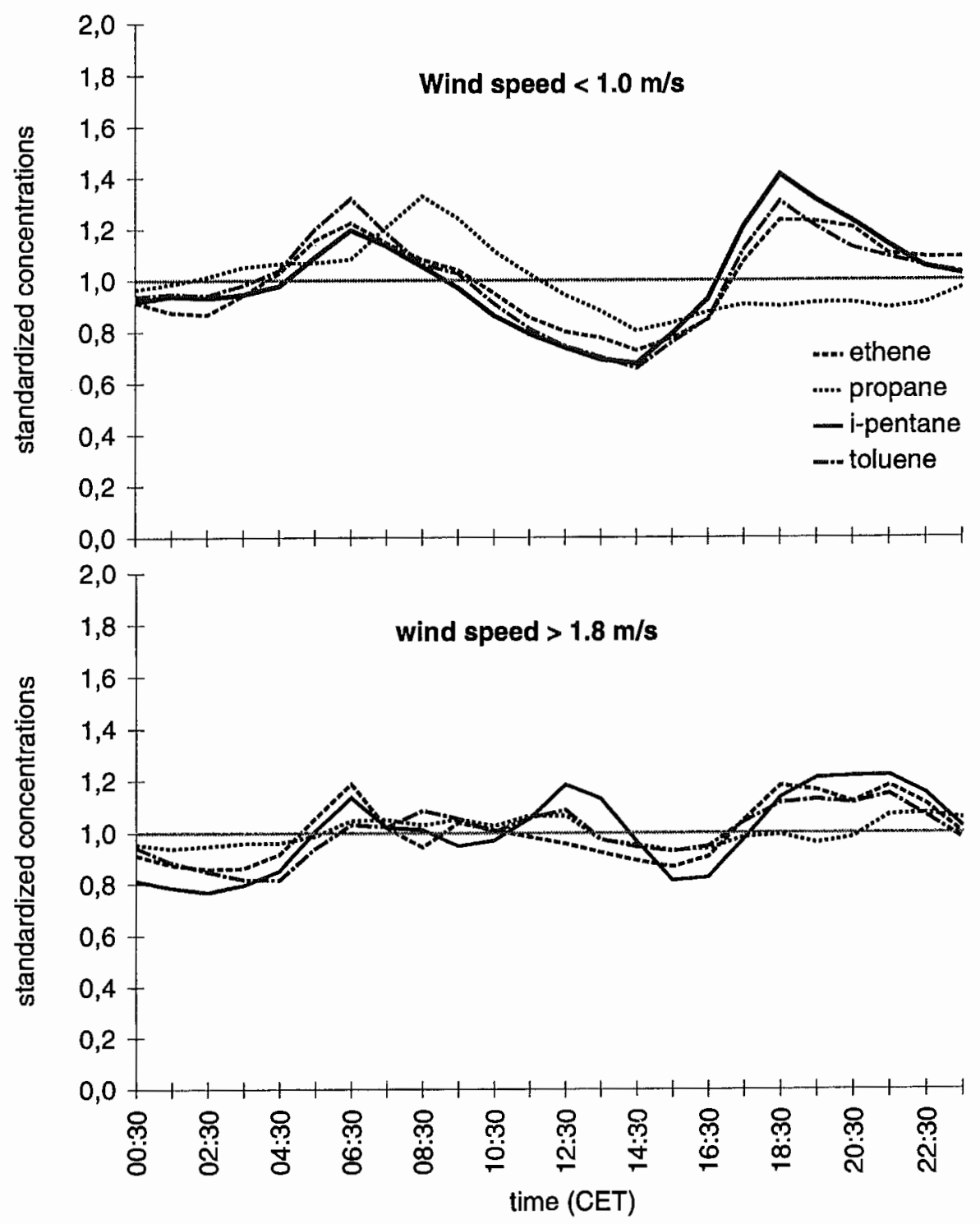

Figure 4. Diurnal cycles of standardized hydrocarbon concentrations at Tänikon for wind speeds below $1 \mathrm{~m} \mathrm{~s}^{-1}$ (upper diagram) and above $1.8 \mathrm{~m} \mathrm{~s}^{-1}$ (lower diagram). The hydrocarbon concentrations were standardized by dividing every value by the daily mean concentration.

\section{Seasonal and Geographical Distribution of VOC}

The concentration of hydrocarbons at a given location is determined by the emission source strength, the mixing with background air due to advection and turbulent diffusion, and the chemical loss. Thus, the time scale of transport from the emission areas compared to the chemical life time, determines how much of each individual 
Table IV. Comparison of noon samples vs. daily means, with and without three special events. Slope of linear regression $\bar{x}_{\text {noon }}=a \cdot x_{\text {mean }}+b$ at Tänikon, correlation coefficient $r$ and number of compared data pairs $n$

\begin{tabular}{|c|c|c|c|c|c|c|c|c|}
\hline & \multicolumn{4}{|c|}{ All values } & \multicolumn{4}{|c|}{3 Events rejected } \\
\hline & $a$ & $b[\mathrm{ppt}]$ & $r$ & $n$ & $a$ & $b$ [ppt] & $r$ & $n$ \\
\hline Ethene & 0.890 & -68 & 0.952 & 71 & 0.886 & -70 & 0.947 & 68 \\
\hline Propane & 0.893 & 36 & 0.968 & 69 & 0.887 & 36 & 0.967 & 66 \\
\hline$i$-Butane & 0.918 & 25 & 0.886 & 72 & 0.828 & 35 & 0.939 & 69 \\
\hline$i$-Pentane & 0.826 & 64 & 0.781 & 73 & 0.730 & 76 & 0.922 & 70 \\
\hline$n$-pentane & 0.851 & 19 & 0.892 & 73 & 0.823 & 11 & 0.947 & 70 \\
\hline Benzene & 0.824 & 14 & 0.934 & 69 & 0.824 & 3 & 0.945 & 66 \\
\hline Toluene & 0.739 & 93 & 0.848 & 69 & 0.727 & 87 & 0.847 & 66 \\
\hline
\end{tabular}
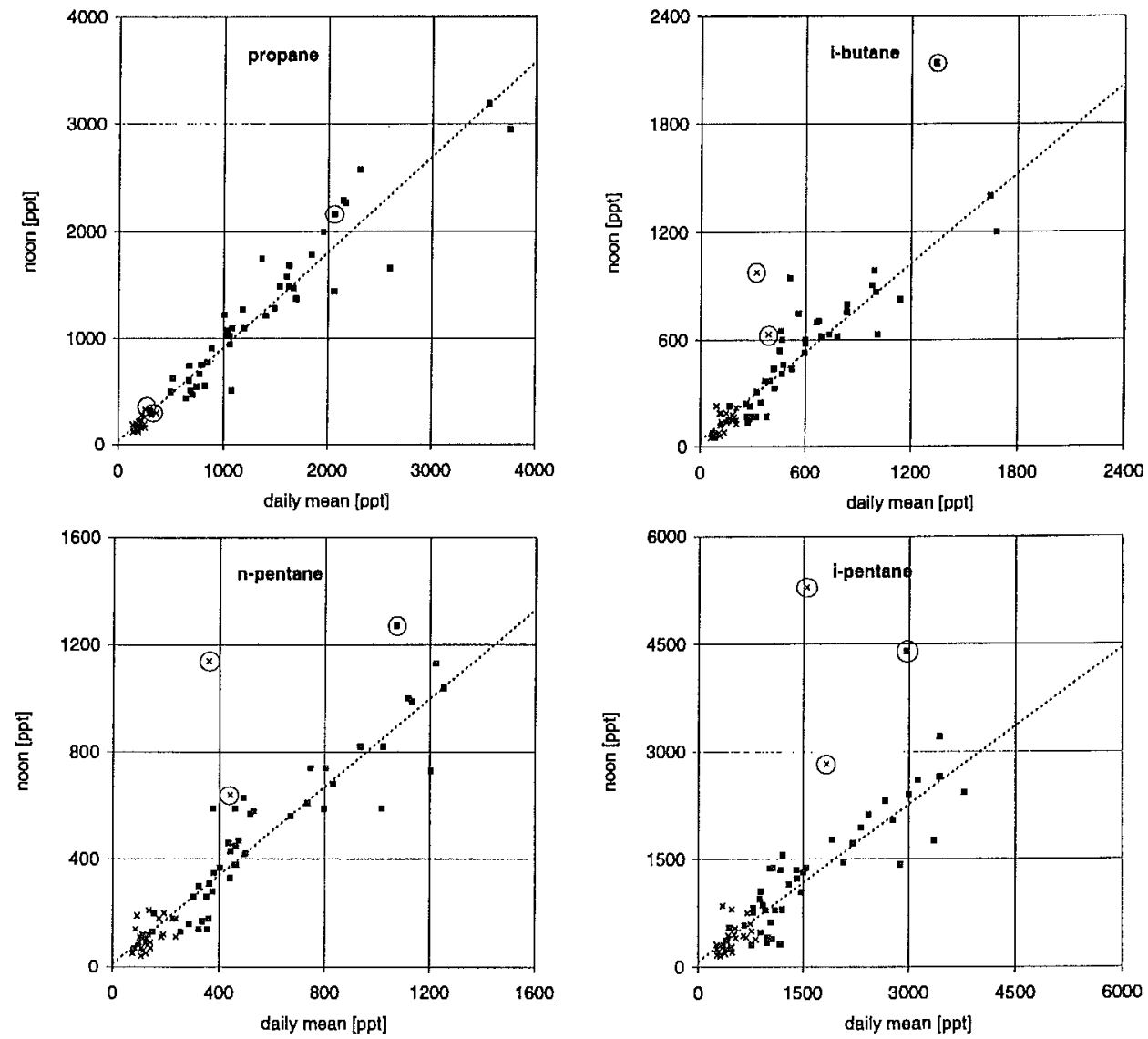

Figure 5. Noon concentrations as a function of the daily means for a number of hydrocarbons based on the continuous sampling at Tänikon. Samples from 1 August-15 September are marked by x'es, whereas samples from 16 September-31 December are marked by filled squares. The dotted lines mark the linear regression lines, calculated when the encircled values were not included. 
Table V. Chemical lifetimes of VOC in winter and summer (days). The values were based on $[\mathrm{OH}]=2 \cdot 10^{5}$ molecules $\mathrm{cm}^{-3}$ in winter, $[\mathrm{OH}]=2 \cdot 10^{6}$ molecules $\mathrm{cm}^{-3}$ in summer, $\left[\mathrm{O}_{3}\right]=1 \cdot 10^{12}$ molecules $\mathrm{cm}^{-3}, T=273 \mathrm{~K}$ in winter and $T=298 \mathrm{~K}$ in summer. Reaction rate constants from Atkinson (1990), Atkinson et al. (1992) and Wirtz et al. (1994)

\begin{tabular}{lcc} 
& Lifetime, winter (d) & Lifetime, summer (d) \\
\hline Ethane & 311 & 23 \\
Ethene & 4 & 0.6 \\
Acetylene & 71 & 6.5 \\
Propane & 62 & 5 \\
Propene & 0.9 & 0.2 \\
$n$-Butane & 24 & 2.3 \\
$i$-Butane & 27 & 2.5 \\
$n$-Pentane & 16 & 1.5 \\
$i$-Pentane & 16 & 1.5 \\
Isoprene & 0.4 & 0.05 \\
Formaldehyde & 6 & 0.6 \\
Acetaldehyde & 3 & 0.4 \\
Acetone & 307 & 26 \\
\hline
\end{tabular}

component of the original plume will survive the transport. Reactive components may be totally lost, and the concentration measured at a rural site may only reflect local emissions.

Table $\mathrm{V}$ shows typical chemical lifetimes of a number of VOC based on the reaction with $\mathrm{OH}$ and ozone for winter and summer conditions, respectively. These life times were calculated by assuming an $\mathrm{OH}$ concentration of $2 \cdot 10^{5}$ and $2 \cdot 10^{6}$ molecules $\mathrm{cm}^{-3}$ in winter and summer, respectively, $\mathrm{T}=273 \mathrm{~K}$ and $298 \mathrm{~K}$ in winter and summer, respectively, and an ozone concentration of $1 \cdot 10^{12}$ molecules $\mathrm{cm}^{-3}$ in both seasons. Reaction rate constants from Atkinson (1990), Atkinson et al. (1992) and Wirtz et al. (1994) were applied. Note that photolysis was not considered, which implies that the actual chemical life times of the carbonyl compounds in Table $\mathrm{V}$ are shorter than the tabulated values.

In winter the chemical lifetimes of hydrocarbons are prolonged due to the low concentration of $\mathrm{OH}$ and the weaker UV-radiation compared to in summer. Furthermore, the height of the mixed boundary layer are often lower in winter than in summer. Thus, if the emission strength is fairly constant during the year, a pronounced seasonal cycle with high concentrations in winter and low in summer is expected for the hydrocarbons, which is indeed observed.

Isaksen et al. (1985) discussed the transport of organic gases into the Arctic, and found that in summer the chemical lifetime of most components (except ethane) is shorter than the characteristic transport time from Europe into the Arctic, whereas in winter, the transport time from $40-60^{\circ} \mathrm{N}$ to $80^{\circ} \mathrm{N}$ is comparable to, or shorter than 
the chemical lifetime (Table $\mathrm{V}$ ) of a number of hydrocarbons. The characteristic time of transport from mid Europe $\left(50^{\circ} \mathrm{N}\right)$ into the Arctic $\left(80^{\circ} \mathrm{N}\right)$ in winter was estimated to be of the order of 10 days in a 2-d model calculation by Isaksen $e t$ al. (1985), whereas an annual average value of 1.8 months (assuming a meridional eddy coefficient, Kyy, of $1 \cdot 10^{6} \mathrm{~m}^{2} \mathrm{~s}^{-1}$ ) is given by Warneck (1988). Iversen (1989) calculated a frequency of high meridional index of $10-30 \%$ in winter for the longitudes $10^{\circ} \mathrm{W}$ to $20^{\circ} \mathrm{E}$. The high meridional index corresponded to a poleward geostrophic wind of at least $10^{\circ}$ latitude/(1.5 days). For a latitudinal span of $20^{\circ}$, approximately the distance from Birkenes to Ny-Ålesund, and assuming a $20 \%$ frequence of high meridional index, this would indicate a transport time of the order of 15 days in winter. The chemical lifetimes of ethane, propane and acetylene in winter are much longer than 10-15 days, while the chemical lifetime of butanes and pentanes is of the same order as this transport time. One would therefore expect a gradual build-up of many components in the northern troposphere (north of $50^{\circ} \mathrm{N}$ ) during the winter months.

Table VI gives the monthly mean and median concentrations of the $\mathrm{C}_{2}-\mathrm{C}_{5}$ hydrocarbons as well as formaldehyde, acetaldehyde and acetone for the different stations calculated by taking measurements from all available years together. The tabulation of monthly data is included to ease the application of the measurements e.g. among modellers. Mean values are most often presented in the literature, but median values are also essential when studying components with a large spread in the concentrations. For the two Norwegian TOR stations, Zeppelin Mountain and Birkenes, the number of hydrocarbon observations were between 40 and 100 for each month except for propene. For the other sites (the EMEP VOC stations) there was between 12 and 25 observations for each month. Rucava was an exception to this with only 6-9 observations in each of the months June-September, due to the contamination problem in 1994 as explained in Chapter 2. The monthly carbonyl values were mostly based on 13-18 measurements.

\subsection{SEASONAL AND MERIDIONAL GRADIENTS IN HYDROCARBONS}

Figure 6 shows the average seasonal cycle at different stations of the sum of the $\mathrm{C}_{2}-$ $\mathrm{C}_{5}$ alkanes, alkenes and alkyne (on carbon basis), as well as the sum of three groups of components, representative of different source categories: Ethane + propane ('natural gas'), ethene + acetylene + propene ('exhaust') and $\mathrm{C}_{4}-\mathrm{C}_{5}$ alkanes ('fuel vapour'). The curves in Figure 6 show the 30 days' running average applied twice to the data for all years taken together. The effect of the second averaging was only to reduce the small scale noise which results when calculating running averages of scattered data.

The build-up of hydrocarbons during winter is clearly visible from Figure 6 when comparing the sum of hydrocarbons at Birkenes and the Zeppelin Mountain. The sum of hydrocarbons reaches an equilibrium level of about $20 \mathrm{ppbC}$ at Birkenes in winter, while on the Zeppelin Mountain, $2000 \mathrm{~km}$ further north, there is a gradual 

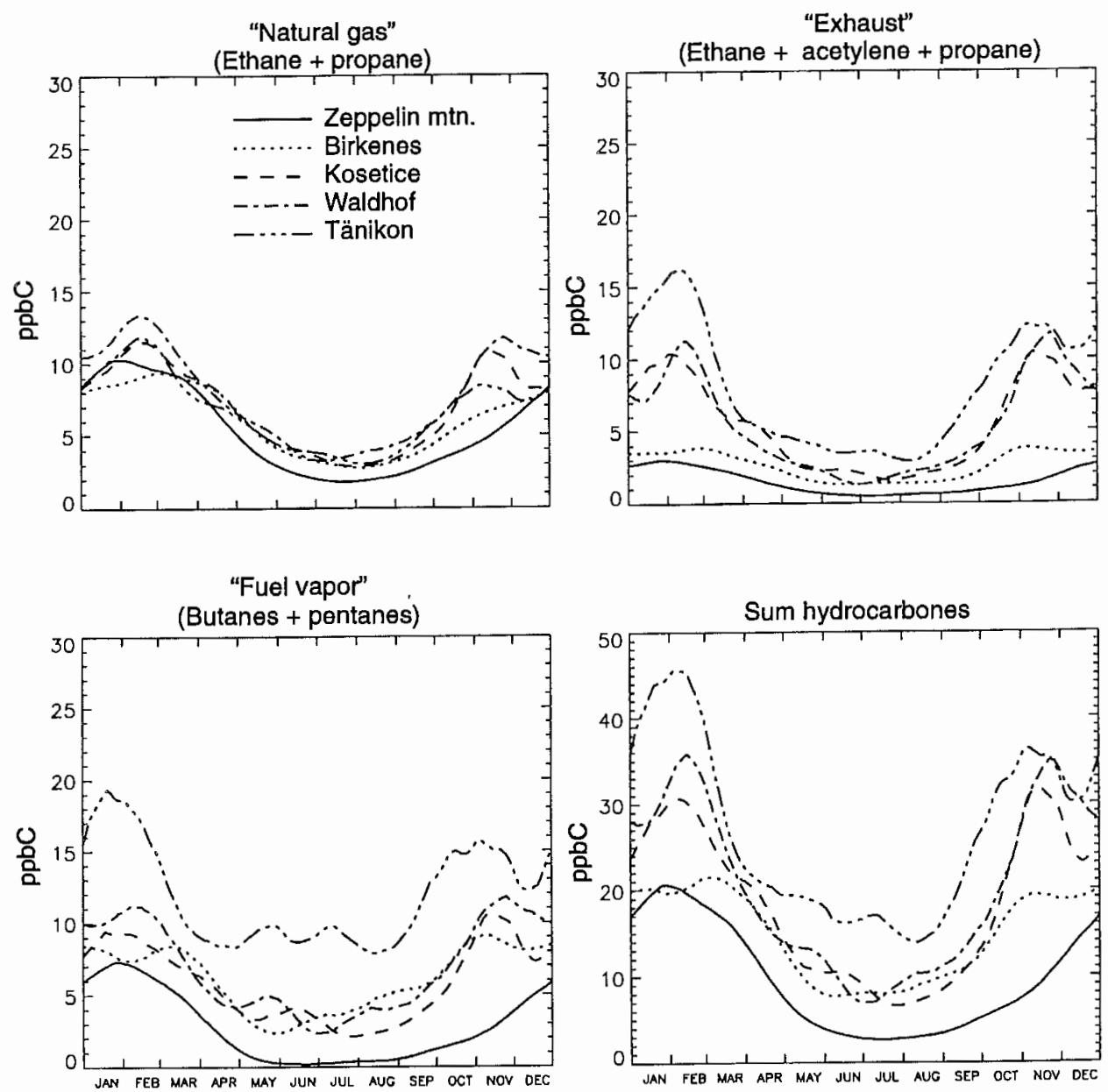

Figure 6. Average seasonal cycles of the sums of different groups of hydrocarbons for several measuring sites. All components were summed on a carbon basis. The lower right diagram shows the total sum of the three other groups shown in the other diagrams (ethane + propane + ethene + acetylene + propene $+n$-butane $+i$-butane $+n$-pentane $+i$-pentane). The seasonal cycles were calculated by a 30 days' running average applied twice and using all available data.

rise in concentration during autumn and winter, which peaks at the same level in late January. The winter value of $20 \mathrm{ppbC}$ compares well with 2-dimensional (Strand and Hov, 1994) and 3-dimensional model calculations (Berntsen and Isaksen, 1994). For $60^{\circ} \mathrm{N}$ Strand and Hov (1994) calculated a nearly constant value of about $20 \mathrm{ppbC}$ for the first 50 days of the year, and about $5 \mathrm{ppC}$ for the summer. The summer value is lower than the observed summer average for Birkenes, but this is explained by regional transport episodes which is not captured in a 2-d model. Berntsen and Isaksen (1994) applied a global 3-dimensional model with detailed photochemistry, based on a chemical tracer model with grid squares of $8^{\circ}$ latitude 
by $10^{\circ}$ longitude. For the grid square containing Spitsbergen they calculated a sum of hydrocarbons of 20-25 ppbC from January to the start of March and a drop in concentration to approximately $5 \mathrm{ppbC}$ in summer, which is in good accordance with our observations.

When the EMEP sites are considered, quite large differences in the sum of $\mathrm{C}_{2}-\mathrm{C}_{5}$ hydrocarbons were found among the stations in winter. However, except for Tänikon, these differences are largely explained by differences in components linked to vehicle combustion, indicated by the sum of ethene, acetylene and propene, the 'exhaust' category. The average seasonal cycles of both the natural gas category and the fuel vapour category were similar for Birkenes, Waldhof and Kosetice. In late winter (February) the differences from the Zeppelin Mountain in the Arctic to Kosetice in central Europe become small, except for the exhaust category compounds. Tänikon differed from this because the components linked to fuel vapour were substantially higher than the other stations, probably due to local emissions. However, the average seasonal cycle in the sum of ethane and propane at Tänikon agreed well with the other sites.

The difference in seasonal cycles of the VOC groups could be explained in several ways. One possible explanation is that the three continental sites were influenced by more local sources from combustion than from other sources in winter. On the other hand, the observations could also be explained by non-constant emission source strengths over the year. Urban hydrocarbon measurements in Switzerland indicate a summer maximum in evaporative fuel compounds and a winter maximum in combustion products (ATAL, 1994). Estimates by Bailey et al. (1990) indicate that emissions of acetylene, ethene and propene are higher during 'cold starts' of the vehicles compared to 'hot starts', whereas the opposite is the case for $i$-butane, $n$-butane and $i$-pentane. A summer maximum in the fuel evaporation and a winter maximum in the emission of combustion products is qualitatively in agreement with the observed seasonal cycles shown in Figure 6.

Figure 7 and Figure 8 show the mean, median, 10-, 25-, 75- and 90-percentile for ethane, ethene, acetylene, propane, $n$-butane and $i$-pentane for winter and for summer. Winter was defined as December through February, and summer was defined as June through August. The stations are arranged from north to south. In winter there is a general increase in the ethene and acetylene concentration from the northern to the southern sites, which is consistent with the increase in observed $\mathrm{NO}_{2}$ and in the regional $\mathrm{NO}_{x}$ emission as discussed in Section 2 and Table II. The average ethane and propane concentration is highest at Waldhof, suggesting a maximum in the leakage of natural gas in this region. Figure 7 shows that the meridional concentration gradients become small even for $n$-butane and $i$-pentane, when comparing the winter medians, except for Tänikon. This shows that the hydrocarbons build up in the remote northern troposphere during winter. The measurements suggest that alkanes from $\mathrm{C}_{2}$ to $\mathrm{C}_{5}$ become quite well mixed from central Europe into the Arctic. 
Ethane

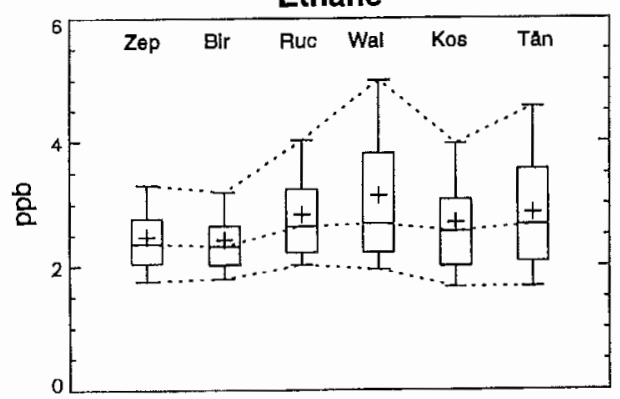

Actylene

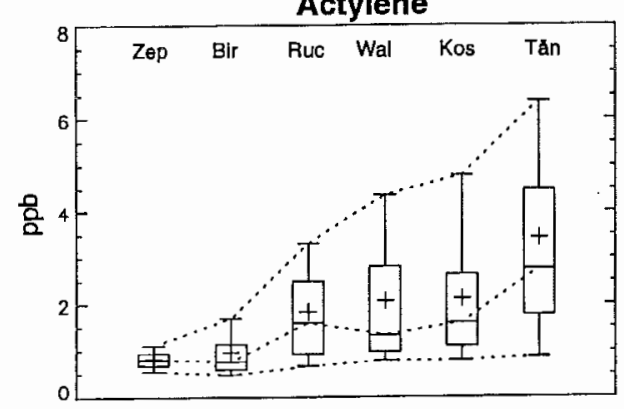

N-butane

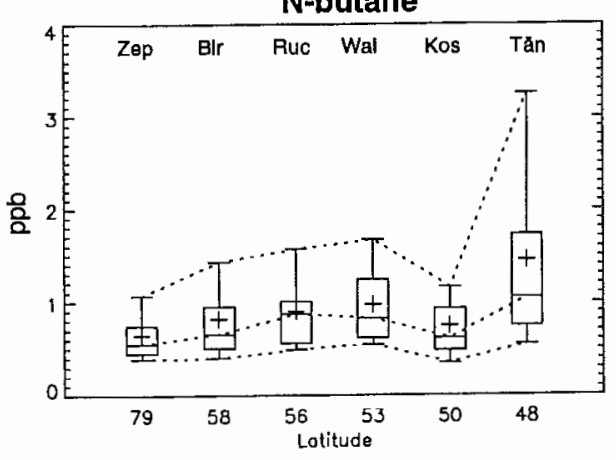

Ethene

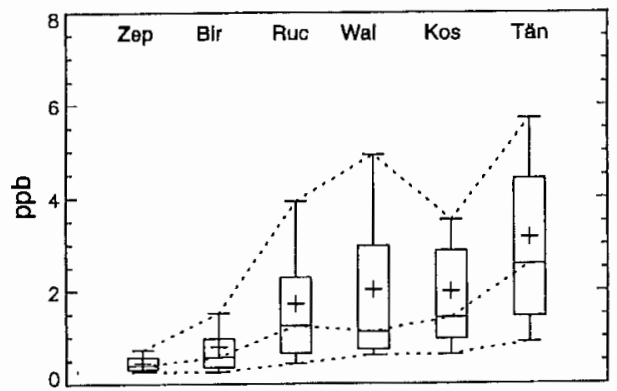

Propane

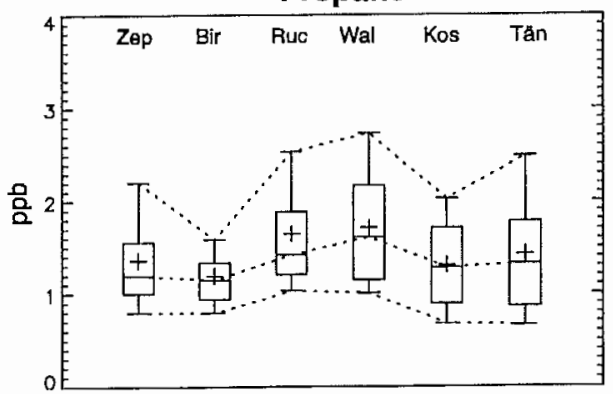

I-pentane

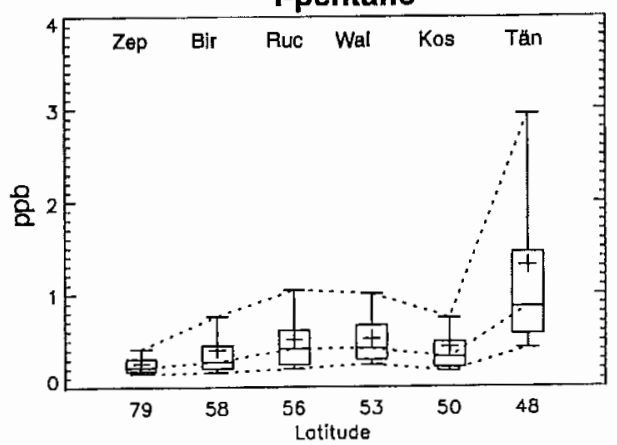

Figure 7. Box- and whisker-diagrams showing percentiles and mean concentrations of observed hydrocarbons in three winter months (December-February) at the Zeppelin Mountain, Birkenes, Rucava, Waldhof, Kosetice and Tänikon. The stations are arranged from north to south. The markers indicate the 10- and 90-percentiles (lower and upper bonds), 25- and 75-percentiles (lower and upper boundaries of boxes), medians (horizontal line inside boxes) and means (crosses). The dotted lines connect the 10- and 90-percentiles and the medians for clarity. All values are in ppb.

In summer the situation is quite different, as seen by Figure 8. $\mathrm{N}$-butane and $i$-pentane almost disappear on the Zeppelin Mountain. At the other sites the spread in the summer data values is larger than in winter, indicating a low background 
concentration superimposed by episodes of high concentrations. Ethane is the only compound which still show a fairly even meridional distribution from Europe into the Arctic, and the concentration on the Zeppelin Mountain is about $80 \%$ of the concentration in Europe. The corresponding ratios for propane and acetylene are about $25-30 \%$. These numbers would indicate an average time scale for the exchange between Europe and $79^{\circ} \mathrm{N}$, of only around 7 days based on photochemical decay only and assuming no sources in between. As the actual time scale for this process is considerably longer on average in summer, closer sources could also contribute.

The alkenes are certainly not subject to long range transport in summer. The lifetimes of ethene and propene are less than one day in summer, still these compounds show a small gradient from north to south (Figure 8 and Table VI). The only explanation for this is the presence of local sources near the measuring sites. Propene has a chemical lifetime of only a few hours in summer, implying that concentrations exceeding a value of the order of $10 \mathrm{ppt}$ are most likely caused by emissions near the measuring site. It is almost impossible to avoid that minor local emissions on occasions affect rural monitoring sites, but the contribution will be negligible most of the year, as long range transport from the major source areas will dominate the observed concentrations. In summer, however, short lived hydrocarbons may be totally depleted during long range transport, and the observations will only reflect the scattered minor emissions near the site. Local emissions could be due to a small anthropogenic source, but ethene and propene is also released by biogenic sources in summer, both from the ocean (Rudolph et al., 1993; Ratte $e t$ al., 1993), and from vegetation (Volz-Thomas et al., 1993).

At Tänikon, where local traffic is known to influence the concentrations, there is a substantial spread in the summer data for all compounds, in contrast to the observations on the Zeppelin Mountain where propene show a much larger spread in observed concentrations than compared to acetylene and the $C_{4}$ and $C_{5}$ alkanes. This is an indication that the local sources influencing the Zeppelin Mountain are not anthropogenic, but more likely of biogenic origin. However, this has to be analysed in more detail to draw firm conclusions.

\subsection{SEASONAL AND GEOGRAPHICAL GRADIENTS IN CARBONYL COMPOUNDS}

Figure 9 shows the average seasonal cycle of formaldehyde, acetaldehyde, acetone and the carbon sum of all analysed carbonyl compounds for Birkenes, Rucava and Mace Head (left diagrams) and Waldhof, Kosetice, Donon, Ispra and Montelibretti (right diagrams). The curves were calculated by a 30 days' running average applied twice, as for the hydrocarbons explained above. The results from Harwell and the Zeppelin Mountain are not included in the figures, due to the less frequent sampling and poorer data coverage at these locations. For Montelibretti the number of samples were too few to calculate a representative seasonal average in spring, and for Mace Head the number of samples from May to September were too few 
Table VI. Monthly mean and median concentrations (1st and 2nd line, respectively) of hydrocarbons and carbonyl compounds at EMEP and Norwegian TOR sites, based on several years of measurements. Unit: ppt

\begin{tabular}{|c|c|c|c|c|c|c|c|c|c|c|c|c|}
\hline & JAN & FEB & MAR & APR & MAY & JUN & JUL & AUG & SEP & OCT & NOV & DEC \\
\hline & \multicolumn{12}{|c|}{ Ethare } \\
\hline \multirow[t]{2}{*}{ Zeppelin } & 2715 & 2702 & 2726 & 2215 & 1492 & 1054 & 809 & 808 & 997 & 1222 & 1558 & 2049 \\
\hline & 2468 & 2576 & 2690 & 2251 & 1484 & 1090 & 802 & 771 & 1000 & 1216 & 1498 & 1993 \\
\hline \multirow[t]{2}{*}{ Birkenes } & 2566 & 2630 & 2780 & 2622 & 1922 & 1292 & 1052 & 958 & 1158 & 1646 & 1994 & 2117 \\
\hline & 2441 & 2528 & 2657 & 2560 & 1825 & 1260 & 978 & 915 & 1103 & 1485 & 1863 & 2004 \\
\hline \multirow[t]{2}{*}{ Rucava } & 2604 & 2897 & 3114 & 2555 & 1982 & 1297 & 1038 & 915 & 1233 & 1812 & 2258 & 2946 \\
\hline & 2403 & 2713 & 2735 & 2551 & 2017 & 1219 & 950 & 924 & 1082 & 1788 & 2056 & 2781 \\
\hline \multirow[t]{2}{*}{ Waldhof } & 2753 & 3906 & 3132 & 2541 & 1969 & 1329 & 1137 & 1222 & 1490 & 1958 & 3164 & 2864 \\
\hline & 2288 & 3284 & 2817 & 2504 & 1990 & 1185 & 1017 & 1017 & 1464 & 1913 & 2880 & 2498 \\
\hline \multirow[t]{2}{*}{ Kosetice } & 2498 & 3440 & 2859 & 2829 & 1894 & 1343 & 1049 & 1034 & 1609 & 1858 & 3026 & 2371 \\
\hline & 2529 & 3068 & 2599 & 2800 & 1826 & 1364 & 985 & 980 & 1398 & 1675 & 2294 & 2115 \\
\hline \multirow[t]{3}{*}{ Tänikon } & 2833 & 3362 & 2808 & 2317 & 1809 & 1275 & 1109 & 1002 & 1525 & 1950 & 2301 & 2567 \\
\hline & 2748 & 3014 & 2526 & 2350 & 1780 & 1265 & 1146 & 1033 & 1452 & 1767 & 2058 & 2227 \\
\hline & \multicolumn{12}{|c|}{ Ethene } \\
\hline \multirow[t]{2}{*}{ Zeppelin } & 515 & 408 & 232 & 147 & 118 & 102 & 96 & 143 & 139 & 181 & 284 & 410 \\
\hline & 452 & 360 & 216 & 140 & 106 & 96 & 93 & 128 & 117 & 175 & 221 & 375 \\
\hline \multirow[t]{2}{*}{ Birkenes } & 792 & 815 & 614 & 468 & 335 & 266 & 321 & 307 & 340 & 675 & 811 & 764 \\
\hline & 571 & 659 & 455 & 393 & 251 & 224 & 272 & 274 & 313 & 519 & 591 & 530 \\
\hline \multirow[t]{2}{*}{ Rucava } & 1163 & 1288 & 845 & 656 & 300 & 260 & 202 & 308 & 442 & 1070 & 1131 & 2468 \\
\hline & 739 & 1050 & 794 & 489 & 267 & 160 & 134 & 231 & 344 & 992 & 1277 & 1911 \\
\hline \multirow[t]{2}{*}{ Waldhof } & 1379 & 2734 & 979 & 611 & 382 & 295 & 262 & 467 & 658 & 961 & 2788 & 1952 \\
\hline & 793 & 2290 & 949 & 497 & 291 & 191 & 170 & 293 & 625 & 652 & 1913 & 1119 \\
\hline \multirow[t]{2}{*}{ Kosetice } & 1722 & 2479 & 986 & 930 & 390 & 447 & 232 & 331 & 539 & 1089 & 2195 & 1825 \\
\hline & 1228 & 2055 & 779 & 812 & 325 & 389 & 227 & 297 & 473 & 849 & 1831 & 1281 \\
\hline \multirow[t]{3}{*}{ Tänikon } & 3447 & 3554 & 1594 & 897 & 691 & 610 & 589 & 530 & 1258 & 1687 & 2611 & 2710 \\
\hline & 2463 & 3491 & 1020 & 720 & 497 & 531 & 538 & 518 & 1190 & 1016 & 2338 & 2226 \\
\hline & \multicolumn{12}{|c|}{ Acetylene } \\
\hline \multirow[t]{2}{*}{ Zeppelin } & 908 & 884 & 846 & 576 & 267 & 120 & 85 & 103 & 175 & 263 & 482 & 719 \\
\hline & 890 & 861 & 850 & 599 & 264 & 123 & 82 & 96 & 166 & 263 & 400 & 678 \\
\hline \multirow[t]{2}{*}{ Birkenes } & 994 & 1001 & 942 & 780 & 431 & 215 & 207 & 267 & 334 & 780 & 929 & 922 \\
\hline & 781 & 849 & 824 & 707 & 378 & 198 & 176 & 211 & 288 & 537 & 731 & 679 \\
\hline \multirow[t]{2}{*}{ Rucava } & 1038 & 1814 & 1620 & 1189 & 577 & 365 & 249 & 332 & 508 & 1124 & 1203 & 2425 \\
\hline & 1008 & 1612 & 1405 & 1019 & 486 & 246 & 223 & 320 & 483 & 971 & 1138 & 2109 \\
\hline \multirow[t]{2}{*}{ Waldhof } & 1288 & 3008 & 1579 & 1202 & 706 & 368 & 390 & 498 & 743 & 994 & 2607 & 1948 \\
\hline & 1003 & 2586 & 1075 & 1029 & 673 & 294 & 377 & 346 & 742 & 768 & 2056 & 1319 \\
\hline \multirow[t]{2}{*}{ Kosetice } & 1819 & 2797 & 1632 & 1574 & 739 & 565 & 382 & 481 & 809 & 1228 & 2071 & 1862 \\
\hline & 1741 & 2313 & 1226 & 1645 & 639 & 528 & 320 & 401 & 835 & 980 & 1794 & 1439 \\
\hline \multirow[t]{2}{*}{ Tänikon } & 2395 & 4137 & 2357 & 1447 & 1210 & 844 & 939 & 771 & 1520 & 1942 & 2624 & 3606 \\
\hline & 2025 & 4241 & 1406 & 1311 & 1094 & 747 & 1024 & 714 & 1366 & 1486 & 2261 & 2582 \\
\hline
\end{tabular}


Table VI. (Continued)

\begin{tabular}{|c|c|c|c|c|c|c|c|c|c|c|c|c|}
\hline & JAN & FEB & MAR & APR & MAY & JUN & JUL & $\mathrm{AUG}$ & SEP & OCT & NOV & DEC \\
\hline & \multicolumn{12}{|c|}{ Propane } \\
\hline \multirow[t]{2}{*}{ Zeppelin } & 1580 & 1456 & 1324 & 789 & 261 & 97 & 60 & 100 & 242 & 398 & 608 & 1055 \\
\hline & 1370 & 1288 & 1279 & 782 & 230 & 94 & 50 & 82 & 198 & 374 & 519 & 998 \\
\hline \multirow[t]{2}{*}{ Birkenes } & 1241 & 1308 & 1286 & 1032 & 499 & 300 & 301 & 298 & 410 & 698 & 911 & 1042 \\
\hline & 1182 & 1284 & 1189 & 949 & 419 & 262 & 274 & 260 & 348 & 625 & 835 & 984 \\
\hline \multirow[t]{2}{*}{ Rucava } & 1406 & 1664 & 1562 & 938 & 587 & 223 & 250 & 259 & 411 & 728 & 1151 & 1803 \\
\hline & 1373 & 1525 & 1341 & 932 & 591 & 153 & 187 & 236 & 333 & 691 & 1046 & 1445 \\
\hline \multirow[t]{2}{*}{ Waldhof } & 1639 & 1999 & 1510 & 928 & 611 & 477 & 370 & 531 & 702 & 959 & 1816 & 1567 \\
\hline & 1250 & 1754 & 1373 & 893 & 583 & 322 & 274 & 396 & 589 & 832 & 1607 & 1377 \\
\hline \multirow[t]{2}{*}{ Kosetice } & 1296 & 1670 & 1281 & 974 & 557 & 453 & 268 & 330 & 582 & 755 & 1463 & 1096 \\
\hline & 1405 & 1628 & 1156 & 930 & 512 & 450 & 230 & 294 & 482 & 656 & 1054 & 992 \\
\hline \multirow[t]{3}{*}{ Tänikon } & 1379 & 1707 & 1212 & 852 & 563 & 459 & 445 & 379 & 679 & 972 & 1199 & 1280 \\
\hline & 1401 & 1649 & 1091 & 824 & 582 & 387 & 411 & 388 & 612 & 809 & 986 & 1050 \\
\hline & \multicolumn{12}{|c|}{ Propene } \\
\hline \multirow[t]{2}{*}{ Zeppelin } & 70 & 116 & 61 & 55 & 51 & 59 & 120 & 84 & 51 & 54 & - & 80 \\
\hline & 64 & 78 & 50 & 48 & 48 & 54 & 141 & 85 & 39 & 52 & - & 83 \\
\hline \multirow[t]{2}{*}{ Birkenes } & 157 & 185 & 154 & 114 & 97 & 96 & 139 & 112 & 99 & 185 & 184 & 131 \\
\hline & 104 & 121 & 100 & 88 & 75 & 71 & 83 & 103 & 83 & 114 & 110 & 97 \\
\hline \multirow[t]{2}{*}{ Rucava } & 260 & 246 & 209 & 157 & 114 & 85 & 66 & 93 & 107 & 258 & 215 & 485 \\
\hline & 180 & 174 & 159 & 127 & 131 & 66 & 62 & 98 & 79 & 232 & 223 & 381 \\
\hline \multirow[t]{2}{*}{ Waldhof } & 309 & 438 & 212 & 126 & 129 & 120 & 80 & 133 & 172 & 260 & 546 & 470 \\
\hline & 252 & 381 & 178 & 144 & 130 & 115 & 76 & 99 & 173 & 187 & 333 & 356 \\
\hline \multirow[t]{2}{*}{ Kosetice } & 372 & 336 & 179 & 176 & 115 & 123 & 84 & 197 & 232 & 247 & 373 & 390 \\
\hline & 317 & 326 & 168 & 159 & 128 & 123 & 73 & 111 & 138 & 270 & 328 & 285 \\
\hline \multirow[t]{3}{*}{ Tänikon } & 681 & 571 & 299 & 203 & 194 & 186 & 149 & 144 & 379 & 403 & 576 & 727 \\
\hline & 463 & 521 & 274 & 200 & 170 & 167 & 149 & 137 & 316 & 325 & 490 & 525 \\
\hline & \multicolumn{12}{|c|}{$N$-butane } \\
\hline \multirow[t]{2}{*}{ Zeppelin } & 744 & 673 & 543 & 256 & 53 & 25 & 30 & 33 & 100 & 156 & 282 & 501 \\
\hline & 605 & 574 & 505 & 244 & 46 & 15 & 17 & 25 & 69 & 148 & 236 & 451 \\
\hline \multirow[t]{2}{*}{ Birkenes } & 866 & 791 & 864 & 575 & 255 & 260 & 320 & 428 & 506 & 864 & 857 & 793 \\
\hline & 674 & 626 & 751 & 468 & 208 & 202 & 183 & 208 & 287 & 523 & 587 & 630 \\
\hline \multirow[t]{2}{*}{ Rucava } & 780 & 901 & 900 & 481 & 243 & 109 & 116 & 185 & 230 & 412 & 642 & 1002 \\
\hline & 635 & 881 & 909 & 377 & 261 & 61 & 128 & 114 & 196 & 372 & 664 & 915 \\
\hline \multirow[t]{2}{*}{ Waldhof } & 899 & 1059 & 806 & 443 & 334 & 298 & 237 & 335 & 421 & 580 & 1118 & 962 \\
\hline & 742 & 897 & 672 & 414 & 288 & 181 & 168 & 256 & 368 & 508 & 999 & 794 \\
\hline \multirow[t]{2}{*}{ Kosetice } & 820 & 840 & 733 & 457 & 273 & 314 & 163 & 206 & 343 & 452 & 818 & 646 \\
\hline & 613 & 809 & 520 & 344 & 240 & 280 & 155 & 174 & 269 & 419 & 651 & 539 \\
\hline \multirow[t]{3}{*}{ Tänikon } & 1403 & 1608 & 983 & 886 & 768 & 638 & 818 & 659 & 941 & 983 & 1234 & 1379 \\
\hline & 885 & 1507 & 736 & 679 & 647 & 583 & 707 & 605 & 815 & 708 & 1053 & 847 \\
\hline & & & & & & $I$-but: & & & & & & \\
\hline Zeppelin & 377 & 341 & 281 & 143 & 28 & 9 & 25 & 26 & 55 & 80 & 142 & 268 \\
\hline & 316 & 297 & 268 & 142 & 23 & 7 & 15 & 14 & 34 & 80 & 116 & 237 \\
\hline
\end{tabular}


Table VI. (Continued)

\begin{tabular}{|c|c|c|c|c|c|c|c|c|c|c|c|c|}
\hline & JAN & FEB & MAR & APR & MAY & JUN & JUL & AUG & SEP & $\mathrm{OCT}$ & NOV & DEC \\
\hline \multirow[t]{2}{*}{ Birkenes } & 452 & 419 & 452 & 306 & 134 & 138 & 199 & 287 & 323 & 480 & 445 & 403 \\
\hline & 349 & 325 & 384 & 242 & 113 & 101 & 102 & 113 & 149 & 257 & 295 & 309 \\
\hline \multirow[t]{2}{*}{ Rucava } & 585 & 464 & 491 & 264 & 130 & 65 & 65 & 68 & 104 & 233 & 335 & 510 \\
\hline & 366 & 470 & 480 & 211 & 128 & 35 & 61 & 56 & 99 & 222 & 341 & 453 \\
\hline \multirow[t]{2}{*}{ Waldhof } & 601 & 552 & 424 & 253 & 178 & 151 & 133 & 186 & 234 & 295 & 577 & 521 \\
\hline & 429 & 453 & 362 & 214 & 158 & 95 & 88 & 117 & 207 & 259 & 570 & 482 \\
\hline \multirow[t]{2}{*}{ Kosetice } & 466 & 456 & 322 & 276 & 163 & 178 & 80 & 130 & 197 & 258 & 460 & 366 \\
\hline & 319 & 438 & 274 & 241 & 135 & 154 & 71 & 101 & 173 & 215 & 368 & 298 \\
\hline \multirow[t]{3}{*}{ Tänikon } & 1167 & 740 & 432 & 319 & 279 & 229 & 264 & 202 & 347 & 436 & 559 & 630 \\
\hline & 523 & 750 & 350 & 291 & 281 & 187 & 216 & 182 & 280 & 332 & 441 & 441 \\
\hline & \multicolumn{12}{|c|}{$N$-pentane } \\
\hline \multirow[t]{2}{*}{ Zeppelin } & 270 & 248 & 173 & 66 & 15 & 7 & 12 & 13 & 39 & 56 & 98 & 182 \\
\hline & 227 & 208 & 155 & 64 & 11 & 6 & 7 & 9 & 21 & 53 & 80 & 164 \\
\hline \multirow[t]{2}{*}{ Birkenes } & 342 & 262 & 267 & 190 & 92 & 90 & 109 & 141 & 158 & 294 & 276 & 267 \\
\hline & 243 & 228 & 229 & 145 & 66 & 63 & 68 & 73 & 101 & 209 & 212 & 213 \\
\hline \multirow[t]{2}{*}{ Rucava } & 344 & 498 & 459 & 208 & 117 & 52 & 53 & 57 & 127 & 228 & 322 & 547 \\
\hline & 226 & 366 & 381 & 195 & 108 & 32 & 43 & 49 & 104 & 197 & 330 & 429 \\
\hline \multirow[t]{2}{*}{ Waldhof } & 338 & 414 & 250 & 161 & 254 & 110 & 110 & 169 & 176 & 286 & 545 & 372 \\
\hline & 244 & 318 & 227 & 114 & 104 & 59 & 68 & 101 & 170 & 215 & 431 & 284 \\
\hline \multirow[t]{2}{*}{ Kosetice } & 300 & 325 & 199 & 197 & 155 & 191 & 66 & 120 & 164 & 212 & 379 & 275 \\
\hline & 2.02 & 326 & 176 & 155 & 96 & 146 & 56 & 85 & 142 & 185 & 368 & 202 \\
\hline \multirow[t]{3}{*}{ Tänikon } & 488 & 513 & 321 & 217 & 330 & 242 & 260 & 250 & 361 & 427 & 500 & 505 \\
\hline & 314 & 470 & 287 & 204 & 214 & 216 & 252 & 230 & 287 & 267 & 377 & 345 \\
\hline & \multicolumn{12}{|c|}{$I$-pentane } \\
\hline \multirow[t]{2}{*}{ Zeppelin } & 297 & 271 & 186 & 74 & 12 & 7 & 13 & 10 & 35 & 54 & 105 & 203 \\
\hline & 258 & 225 & 176 & 69 & 9 & 6 & 7 & 8 & 20 & 52 & 86 & 190 \\
\hline \multirow[t]{2}{*}{ Birkenes } & 449 & 346 & 354 & 244 & 131 & 143 & 201 & 265 & 297 & 509 & 450 & 415 \\
\hline & 300 & 276 & 296 & 177 & 96 & 88 & 99 & 101 & 139 & 300 & 309 & 270 \\
\hline \multirow[t]{2}{*}{ Rucava } & 446 & 526 & 629 & 273 & 149 & 73 & 71 & 73 & 142 & 304 & 352 & 559 \\
\hline & 267 & 463 & 477 & 263 & 108 & 44 & 67 & 66 & 120 & 241 & 402 & 547 \\
\hline \multirow[t]{2}{*}{ Waldhof } & 455 & 571 & 374 & 230 & 280 & 176 & 169 & 247 & 270 & 366 & 790 & 532 \\
\hline & 348 & 452 & 342 & 181 & 178 & 99 & 115 & 160 & 257 & 307 & 592 & 427 \\
\hline \multirow[t]{2}{*}{ Kosetice } & 477 & 449 & 294 & 286 & 195 & 271 & 109 & 169 & 274 & 317 & 508 & 399 \\
\hline & 305 & 480 & 2.27 & 223 & 163 & 224 & 96 & 152 & 209 & 288 & 420 & 264 \\
\hline \multirow[t]{3}{*}{ Tänikon } & 1292 & 1319 & 763 & 618 & 786 & 685 & 819 & 693 & 1049 & 1004 & 1142 & 1320 \\
\hline & 630 & 1136 & 575 & 485 & 656 & 555 & 756 & 662 & 816 & 828 & 1015 & 748 \\
\hline & \multicolumn{12}{|c|}{ Formaldehyde } \\
\hline \multirow[t]{2}{*}{ Zeppelin } & - & - & - & 153 & 276 & 271 & - & 197 & 144 & - & - & - \\
\hline & - & - & - & 134 & 272 & 229 & - & 158 & 138 & - & - & - \\
\hline Birkenes & 229 & 386 & 347 & 526 & 827 & 728 & 967 & 671 & 468 & 341 & 292 & 288 \\
\hline & 221 & 299 & 339 & 496 & 753 & 658 & 898 & 654 & 418 & 315 & 284 & 260 \\
\hline Rucava & 614 & 788 & 519 & 991 & 720 & 788 & 899 & 754 & 706 & 710 & 612 & 665 \\
\hline & 607 & 737 & 504 & 946 & 607 & 804 & 796 & 607 & 741 & 607 & 500 & 686 \\
\hline
\end{tabular}


Table VI. (Continued)

\begin{tabular}{|c|c|c|c|c|c|c|c|c|c|c|c|c|}
\hline & JAN & FEB & MAR & APR & MAY & JUN & JUL & AUG & SEP & $\mathrm{OCT}$ & NOV & DEC \\
\hline \multirow[t]{2}{*}{ MaceHead } & - & 378 & 284 & 442 & - & - & - & . & - & - & 426 & 230 \\
\hline & - & 268 & 244 & 307 & - & - & - & - & - & - & 370 & 236 \\
\hline \multirow[t]{2}{*}{ Waldhof } & 408 & 720 & 533 & 870 & 1155 & 1051 & 1714 & 1448 & 894 & 750 & 868 & 460 \\
\hline & 398 & 552 & 406 & 745 & 930 & 906 & 1600 & 1162 & 788 & 670 & 796 & 398 \\
\hline \multirow[t]{2}{*}{ Kosetice } & 873 & 1053 & 973 & 1132 & 1418 & 1616 & 1737 & 1872 & 1206 & 894 & 972 & 743 \\
\hline & 1024 & 898 & 697 & 1028 & 1273 & 1387 & 1647 & 1730 & 1111 & 890 & 954 & 733 \\
\hline \multirow[t]{2}{*}{ Donon } & 571 & 706 & 760 & 887 & 1322 & 1289 & 1372 & 2143 & 738 & 946 & 792 & 452 \\
\hline & 544 & 638 & 630 & 823 & 1210 & 1217 & 1245 & 2329 & 753 & 804 & 713 & 410 \\
\hline \multirow[t]{2}{*}{ Ispra } & 2344 & 2036 & 2394 & 1888 & 2064 & 3439 & 4248 & 3400 & 2054 & 1737 & 2017 & 2026 \\
\hline & 1946 & 1887 & 2616 & 1915 & 2013 & 3018 & 3861 & 3570 & 2029 & 1552 & 2364 & 1946 \\
\hline \multirow[t]{3}{*}{ Montelibretti } & 1162 & 1278 & - & - & - & - & 2948 & 5903 & 2487 & 1359 & - & - \\
\hline & 957 & 1308 & - & - & - & - & 2746 & 6233 & 2273 & 1379 & - & - \\
\hline & \multicolumn{12}{|c|}{ Acetaldehyde } \\
\hline \multirow[t]{2}{*}{ Zeppelin } & - & - & - & 168 & 316 & 98 & - & 80 & 81 & - & - & - \\
\hline & - & - & - & 167 & 236 & 81 & - & 78 & 83 & - & - & - \\
\hline \multirow[t]{2}{*}{ Birkenes } & 221 & 317 & 214 & 280 & 385 & 275 & 483 & 243 & 212 & 240 & 176 & 210 \\
\hline & 158 & 253 & 207 & 236 & 328 & 231 & 441 & 255 & 210 & 220 & 145 & 145 \\
\hline \multirow[t]{2}{*}{ Rucava } & 357 & 457 & 298 & 446 & 334 & 301 & 399 & 351 & 309 & 413 & 314 & 433 \\
\hline & 344 & 411 & 247 & 438 & 306 & 279 & 242 & 253 & 290 & 371 & 236 & 352 \\
\hline \multirow[t]{2}{*}{ MaceHead } & - & 207 & 160 & 217 & - & - & - & - & - & - & 240 & 106 \\
\hline & - & 124 & 129 & 118 & - & - & - & - & - & - & 199 & 116 \\
\hline \multirow[t]{2}{*}{ Waldhof } & 310 & 519 & 356 & 439 & 407 & 325 & 476 & 439 & 391 & 460 & 640 & 343 \\
\hline & 247 & 419 & 301 & 414 & 392 & 258 & 381 & 406 & 352 & 419 & 543 & 293 \\
\hline \multirow[t]{2}{*}{ Kosetice } & 554 & 586 & 557 & 545 & 577 & 728 & 744 & 787 & 540 & 541 & 662 & 373 \\
\hline & 387 & 561 & 419 & 537 & 567 & 763 & 661 & 733 & 513 & 510 & 669 & 328 \\
\hline \multirow[t]{2}{*}{ Donon } & 319 & 420 & 472 & 477 & 734 & 556 & 647 & 789 & 454 & 565 & 524 & 288 \\
\hline & 269 & 344 & 414 & 414 & 685 & 518 & 580 & 827 & 398 & 484 & 430 & 263 \\
\hline \multirow[t]{2}{*}{ Ispra } & 1344 & 1282 & 1320 & 1055 & 991 & 1309 & 1484 & 1383 & 1027 & 1086 & 1229 & 1276 \\
\hline & 1238 & 1330 & 1386 & 1015 & 881 & 1198 & 1343 & 1373 & 981 & 908 & 1418 & 1144 \\
\hline \multirow[t]{2}{*}{ Montelibretti } & 672 & 664 & - & - & - & - & 979 & 1504 & 887 & 699 & - & - \\
\hline & 548 & 639 & - & - & - & - & 981 & 1370 & 776 & 731 & - & - \\
\hline
\end{tabular}

Acetone

\begin{tabular}{lrrrrrrrrrrrr} 
Zeppelin & - & - & - & 538 & 624 & 548 & - & 552 & 494 & - & - & - \\
\multirow{2}{*}{ Birkenes } & - & - & - & 473 & 652 & 518 & - & 505 & 534 & - & - & - \\
\multirow{5}{*}{ Rucava } & - & 333 & 406 & 1120 & 1481 & 1248 & 1220 & 886 & 829 & 562 & 390 & 327 \\
& -397 & 499 & 525 & 1085 & 835 & 773 & 1029 & 823 & 803 & 700 & 651 & 395 \\
\multirow{2}{*}{ Mace Head } & 351 & 520 & 399 & 1109 & 774 & 701 & 852 & 762 & 803 & 591 & 465 & 416 \\
\multirow{3}{*}{ Waldhof } & - & 384 & - & - & - & - & - & - & - & - & 486 & 237 \\
\multirow{4}{*}{ Kosetice } & - & 277 & - & - & - & - & - & - & - & - & 473 & 224 \\
& 609 & 1283 & 1119 & 1325 & 1318 & 1176 & 1629 & 1528 & 1227 & 1153 & 1112 & 669 \\
& 678 & 904 & 717 & 1048 & 1090 & 1011 & 1280 & 1553 & 1007 & 958 & 1154 & 534 \\
& 622 & 752 & 730 & 1329 & 1561 & 1687 & 1594 & 1561 & 1162 & 917 & 858 & 509
\end{tabular}


Table VI. (Continued)

\begin{tabular}{lrrrrrrrrrrrr}
\hline & JAN & FEB & MAR & APR & MAY & JUN & JUL & AUG & SEP & OCT & NOV & DEC \\
\hline \multirow{2}{*}{ Donon } & 738 & 903 & 1108 & 1308 & 1657 & 1847 & 1724 & 2019 & 1125 & 1085 & 969 & 563 \\
& 487 & 856 & 734 & 1282 & 1641 & 1473 & 1551 & 1981 & 1015 & 925 & 848 & 461 \\
\multirow{4}{*}{ Ispra } & 1875 & 1997 & 2184 & 1970 & 1793 & 1650 & 1739 & 1566 & 1495 & 1592 & 2025 & 1837 \\
\multirow{4}{*}{ Montelibretti } & 1704 & 2097 & 2095 & 2005 & 1586 & 1459 & 1476 & 1427 & 1437 & 1308 & 2152 & 1732 \\
& 822 & 855 & - & - & - & - & 1781 & - & 1357 & 1080 & - & - \\
& 823 & 974 & - & - & - & - & 1728 & - & 1349 & 1168 & - & - \\
\hline
\end{tabular}

for this calculation. It is important to bear in mind that the average seasonal cycles presented in Figure 9 are based on a varying number of observations from site to site and from month to month, and that the time period covered by the measurement programme is still rather limited, implying that the results could be biased by random effects.

The average seasonal cycles of the carbonyl compounds are quite different from the hydrocarbons. The sum of carbonyl compounds show a maximum in summer at all the sites, but the seasonal amplitude and the absolute concentrations vary. The comparison of the sum of carbonyl compounds is complicated by the fact that each date with measurements may consist of a varying number of components included in the summation due to concentrations below the detection limit. Although this means that the concentration is low, the sum of a large number of compounds below the detection limits may contribute to the sum, especially when they are summed on a carbon basis.

In winter the sum of carbonyl compounds is about 12 ppbC at Ispra, a factor of $3-$ 10 higher than for the sites further north, and even twice the value for Montelibretti. Birkenes and Mace Head show the lowest concentrations of 1-1.5 ppbC in these months. The sum of carbonyls have a broad maximum from May to July at Kosetice and Donon, while at Birkenes the highest average value is found in May. The spring peak in the sum of carbonyls at Birkenes is mostly due to a peak in the acetone concentration. Acetone shows a pronounced seasonal variation at all sites, except at Ispra, while a slight maximum is found in summer for formaldehyde and acetaldehyde at most of the sites.

The seasonal cycle of the carbonyl compounds at Ispra differs substantially from the other sites. The sum of carbonyls at Ispra is the result of a pronounced peak in the formaldehyde concentration in mid summer of $4 \mathrm{ppb}$, compared to an almost constant value of approximately 2 ppb in other parts of the year, and a minimum in the acetone concentration in the summer. Although the number of samples from Montelibretti is fewer, the measurements indicate a peak in the formaldehyde concentration in summer, similar to at Ispra, but later in the year. In winter the concentrations are, however, much less than at Ispra.

The higher carbonyl concentrations at the two Italian sites could possibly reflect a combination of a more efficient oxidation of precursors and higher biogenic 
Ethane

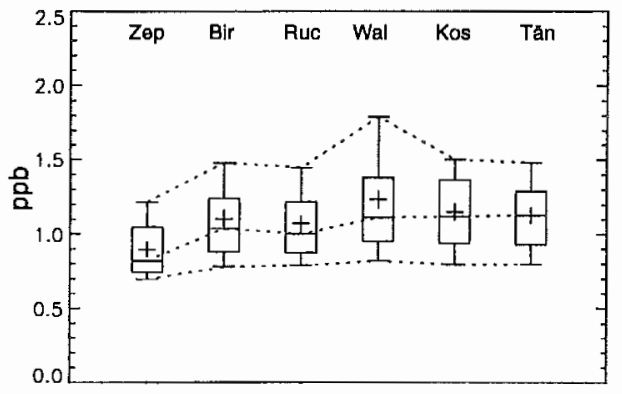

Actylene

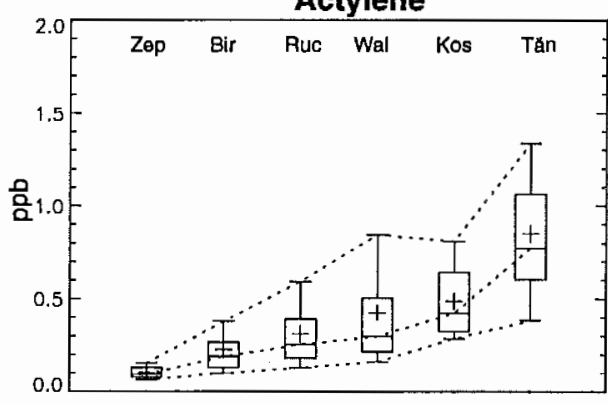

N-butane

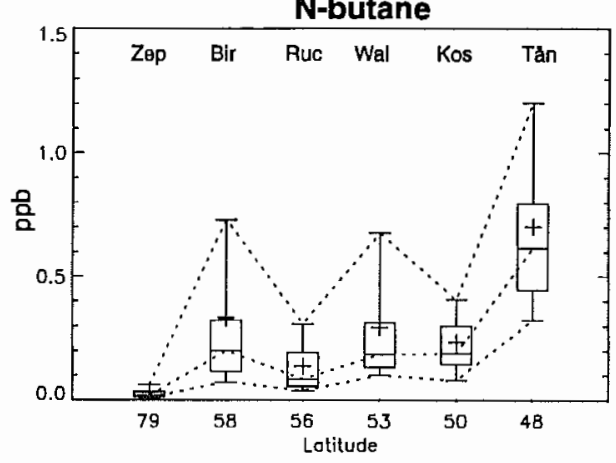

Ethene

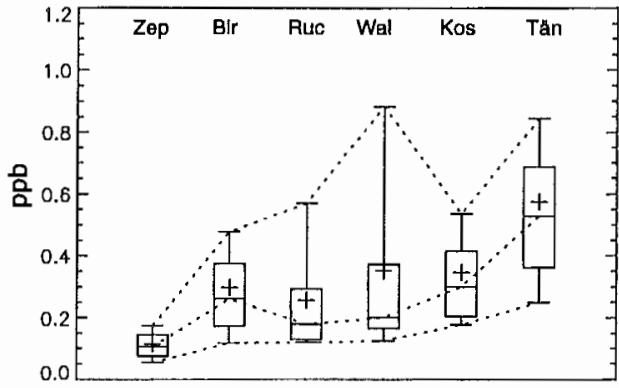

Propane

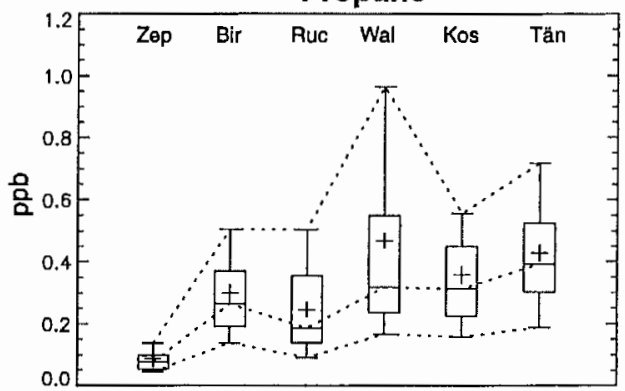

I-pentane

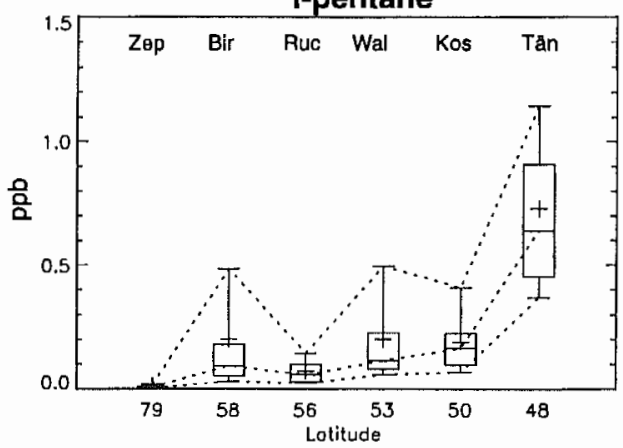

Figure 8. Same as Figure 7 for the three summer months, June-August.

emissions of VOC. It cannot, however, be ruled out that the measurements from the Italian sites are influenced by anthropogenic emissions near the stations as discussed in Chapter 2 and indicated in Table II. In November and December 1994 the average concentrations of ethene and acetylene (analysed by JRC - Ispra) were about twice the monthly average concentrations at Kosetice, and for the $\mathrm{C}_{4}$ and $\mathrm{C}_{5}$ alkanes the difference was larger, about a factor of 3-4 compared to Kosetice. Until a more detailed study of the relationship between carbonyl and anthropogenic 
Formaldehyde

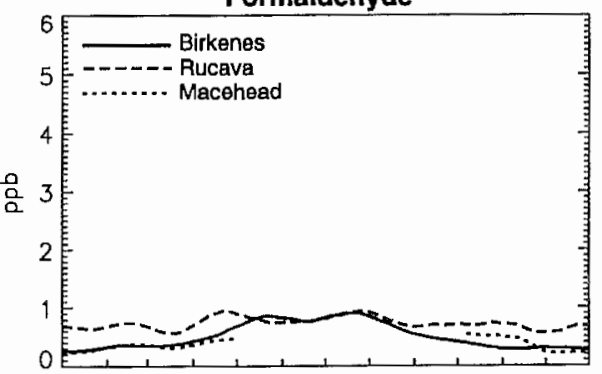

Acetaldehyde
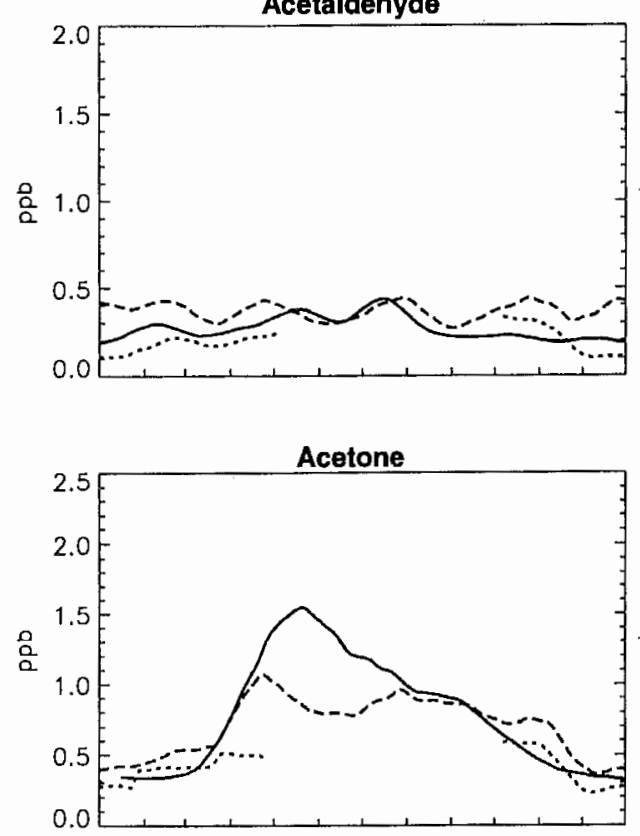

Sum carb

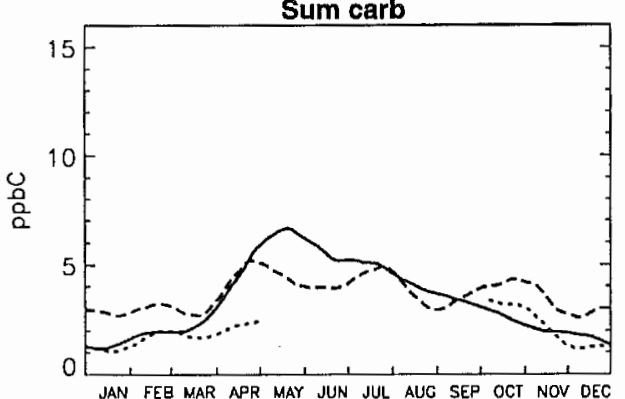

Formaldehyde

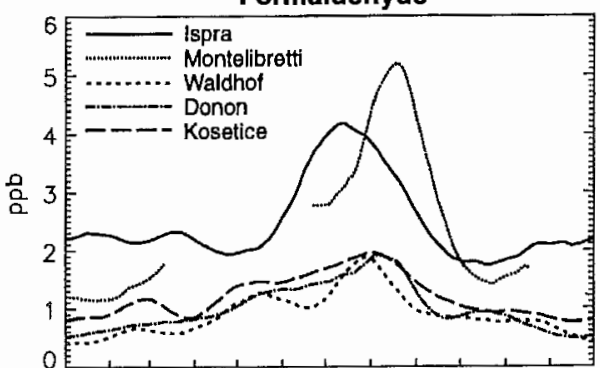

Acetaidehyde

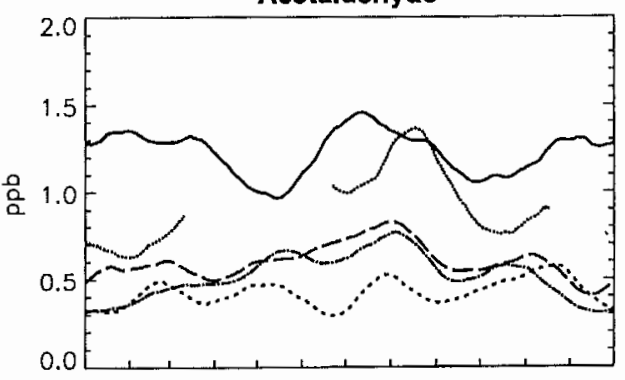

Acetone

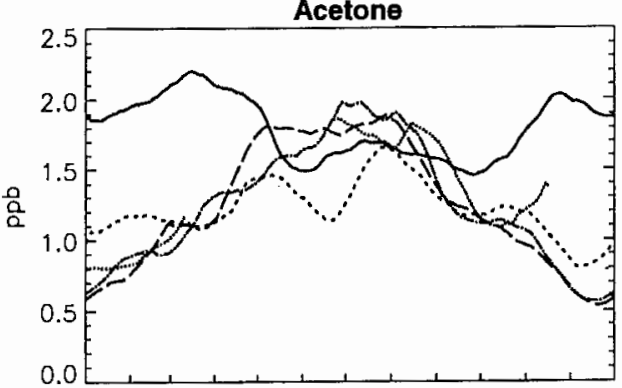

Sum carb

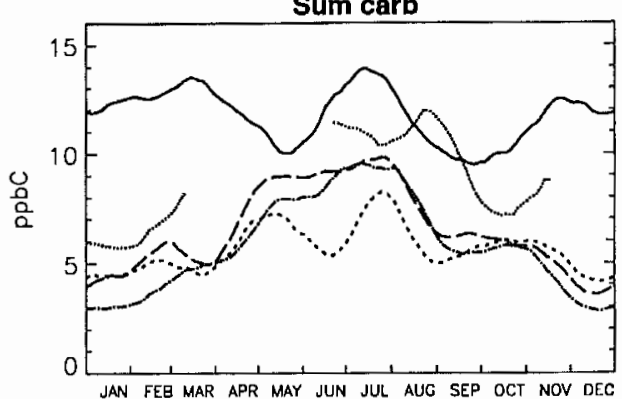

Figure 9. Average seasonal cycles of the sum of all measured carbonyl compounds (ppbC) and of formaldehyde, acetaldehyde and acetone (ppb) for Birkenes, Rucava and Mace Head (left diagrams), as well as for Waldhof, Kosetice, Donon, Ispra and Montelibretti (right diagrams). The seasonal cycles were calculated by a 30 days' running average applied twice and using all available data. 
tracers is performed, the results from Ispra and Montelibretti should be used with care.

Formaldehyde, acetaldehyde and acetone constitutes most of the sum of measured carbonyl compounds. These three compounds contribute on the average $85-95 \%$ of the total carbon sum of carbonyls through the year, and no seasonal cycle was found for the fraction of these compounds compared to the sum. Analysis of the higher order carbonyls is still important, because these compounds are more specific tracers of certain reaction pathways, and of the oxidised species, than the low-weight carbonyls.

Figure 10 shows the box and whisker diagrams for the winter and summer seasons for the carbonyls, similar to Figure 7 and 8 for the hydrocarbons. Measurements from May were included in the summer season for the carbonyls. The carbonyls were measured on a daily basis from April to September on the Zeppelin Mountain in 1994, so the Zeppelin Mountain is included in the figure for the summer season.

In December-February the photochemical formation of carbonyls is low, and elevated concentrations should mostly reflect direct anthropogenic emissions, rather than secondary formation. The spread of the measured concentrations in winter is low for Birkenes and Mace Head, indicating few episodes with transport of air masses polluted by carbonyl emissions. The median formaldehyde concentration at these sites is about $250 \mathrm{ppt}$, consistent with reported background values in the literature (Lowe and Schmidt, 1983). The winter values at Kosetice indicate a higher influence from emissions of formaldehyde and acetaldehyde than at the other sites (except for the measurements at the Italian sites). Based on urban measurements in Hungary, Haszpra et al. (1991) argue that the aldehyde emission in that region is higher than in Western Europe, possibly due to the composition of the fleet of vehicles. This is in qualitative agreement with the EMEP measurements, but longer time series are needed to clarify that this finding is really representative for the region.

In winter acetone has a chemical lifetirne of a month or more, sufficient for mixing over large areas. The marked differences in acetone concentration between the sites are therefore surprising. Direct emissions of acetone are apparently much more important at Waldhof, indicated by the large spread in measured concentrations. The average acetone concentrations of $250-400 \mathrm{ppt}$ in winter at the most northern sites in winter is indicative of the tropospheric background value.

The geographical variation in the carbonyl percentiles in summer resembles that in winter in many ways, with some exceptions. There is a general north to south increase in the concentration in summer, as in winter, and the northernmost stations, the Zeppelin Mountain, Birkenes, Rucava and Mace Head seem to fall in a lower concentration regime than the other sites. The formaldehyde concentration on the Zeppelin Mountain is around $250 \mathrm{ppt}$ and shows almost no spread in the data during May-August. We believe this represents the general background concentration in the remote northern troposphere in summer, and the value agrees with values 
calculated from the assumption of a photochemical steady-state and production from methane oxidation only (e.g. Warneck, 1988). It is interesting to note that acetone apparently is mixed into the Arctic even in summer, causing an average concentration of 500-600 ppt on the Zeppelin Mountain.

The reports of carbonyl measurements at rural sites are still rather sparse. Shepson et al. (1991) presented carbonyl measurements from Ontario, Canada, sampled in July-August 1988. They found average concentrations of formaldehyde, acetaldehyde and acetone of about $1.7,0.5$ and $1.7 \mathrm{ppb}$, respectively. These values agree quite well with the average summer concentrations shown in Figure 10 for Kosetice and Donon. Acetone was measured over eastern Canada in July to August 1990 and reported by Singh et al. (1994). They found a mean value of $1.1 \mathrm{ppb}$, while the observed concentrations were in the range from 0.36 to $2.3 \mathrm{ppb}$. They estimated a representative background concentration to be around $0.5 \mathrm{ppb}$. These values are lower than the summer averages for our central European sites, but are in accordance with the concentrations at Birkenes and Rucava.

\subsection{THE FRACTIONATION BETWEEN CARBONYLS AND HYDROCARBONS}

The average seasonal cycles of the fraction of carbonyls compared to the total sum of VOC (hydrocarbons + carbonyls) were calculated for the Zeppelin Mountain, Birkenes, Kosetice and Waldhof and are shown in Figure 11. The percentage fraction of carbonyls to the sum of VOC shows a maximum in summer. Furthermore, the calculated contribution of carbonyls to the sum of VOC are surprisingly similar at all the sites. In winter the carbonyls contribute about 5-15\% to the VOC sum, whereas this fraction rises to $40-50 \%$ in summer. At Kosetice the fraction even peaks at $60 \%$ in July.

The maximum of the carbonyl fraction in summer is consistent with an oxidation of the hydrocarbons leading to a formation of aldehydes and ketones in this season. That the sum of carbonyls is comparable in magnitude with the sum of $\mathrm{C}_{2}-\mathrm{C}_{5}$ hydrocarbons in summer is interesting, and illustrates the importance of performing carbonyl measurements especially in summer. At the moment we would not speculate why the seasonal cycle in the fraction of carbonyls to the sum of VOC seems to be that similar for the different sites. The data may still be biased by random averaging artifacts, hence more measurements are required to draw conclusions.

\section{Conclusions}

Several years' regular measurements of light hydrocarbons and carbonyl compounds at rural sites in Europe have been presented. The stations cover a region from the Mediterranean to the Arctic. The measurements are part of the European monitoring and evaluation programme (EMEP) and the EUROTRAC project Tropospheric Ozone Research (TOR). In addition, half a year with continuous 
Formaldehyde

(December - February)

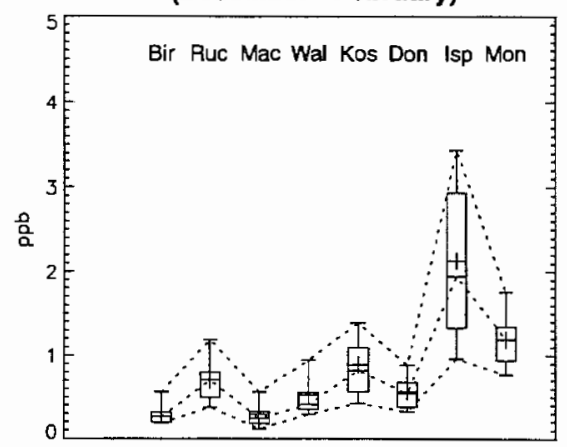

Formaldehyde

(May - August)

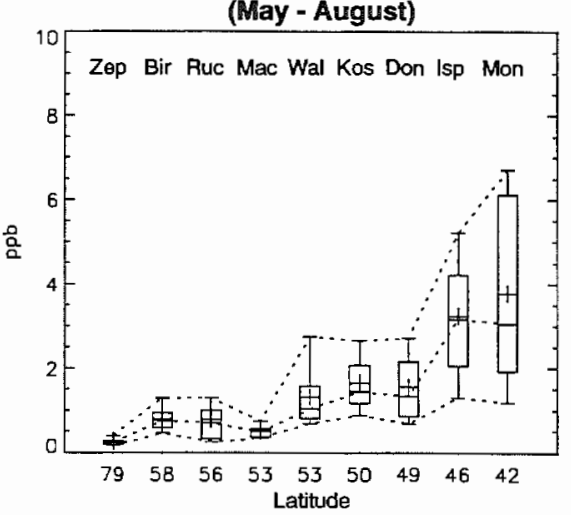

Acetaldehyde

(December - February)

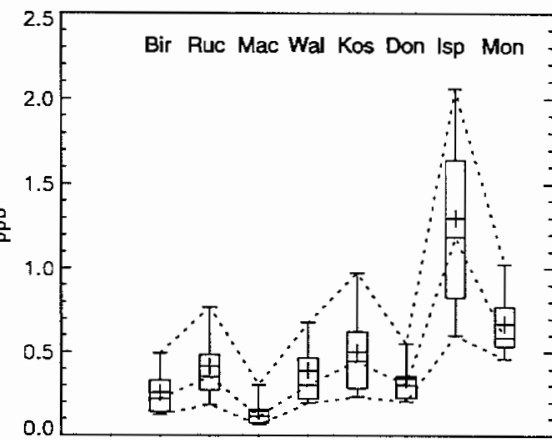

Acetaldehyde

(May - August)

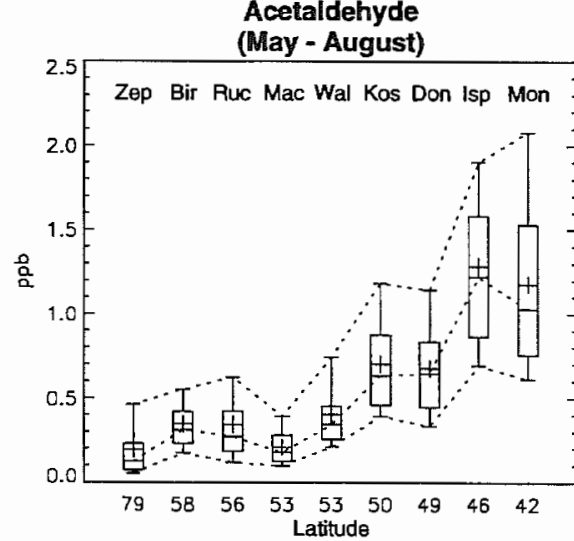

Acetone

(December - February)

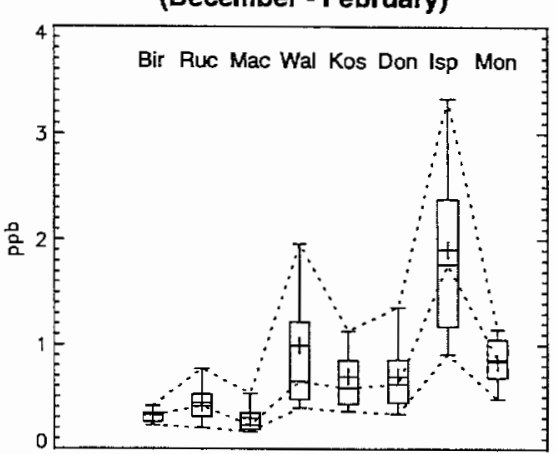

Acetone

(May - August)

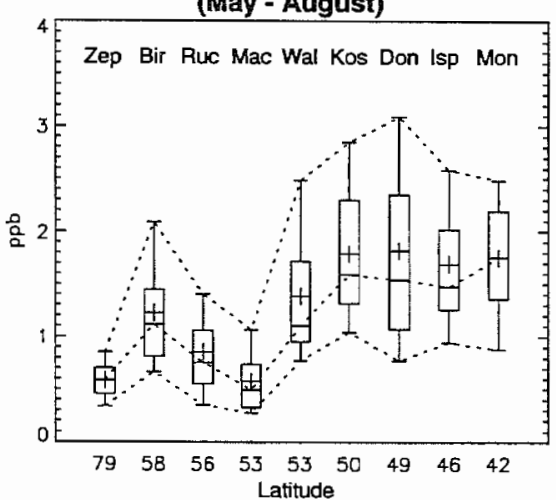

Figure 10. Box- and whisker-diagrams showing percentiles and mean concentrations of observed carbonyl compounds in three winter months (DecemberFebruary) and four summer months (May-Auoust) at the Zeppelin Mountain (summer only), Birkenes, Rucava, Mace Head, Waldhof, Kosetice, Donon, Ispra and Montelibretti. The stations are arranged from north to south. All values are in ppb. The percentiles and means are marked as explained in Figure 7 . 


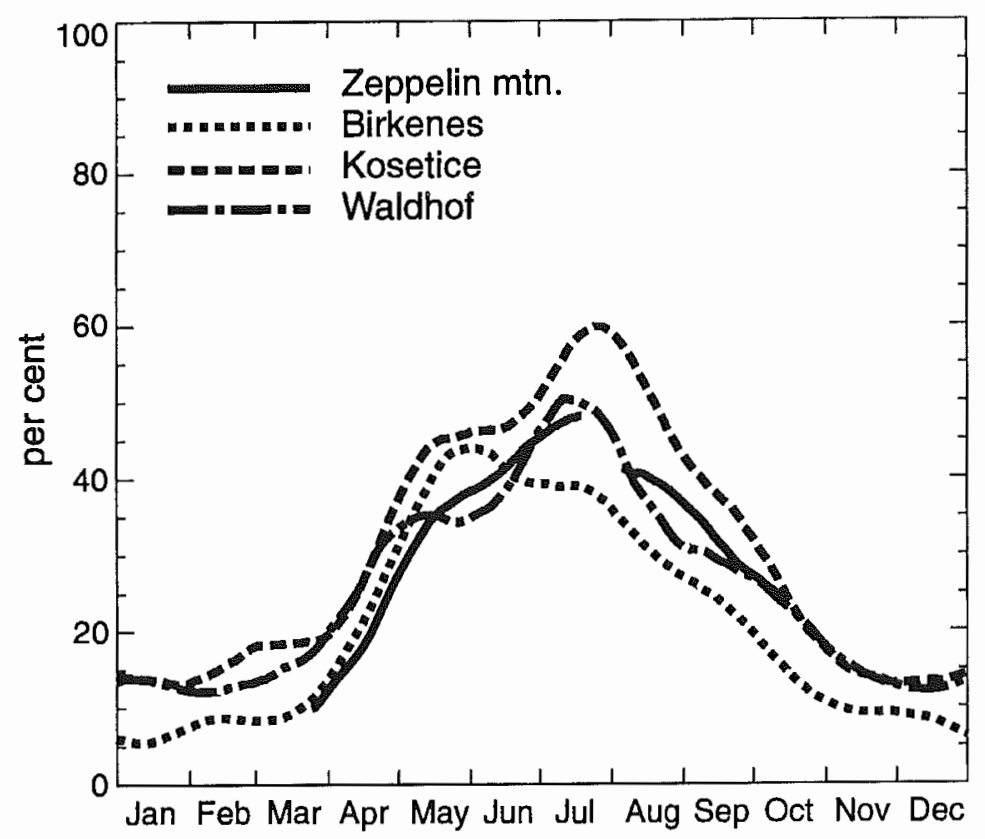

Figure 11. The percentage fraction of the sum of all carbonyl compounds to the total sum of VOC (hydrocarbons + carbonyls) for the Zeppelin Mountain (full line), Birkenes (dotted), Kosetice (dashed) and Waldhof (dash-dot).

sampling of hydrocarbons at Tänikon in Switzerland is included to elucidate the diurnal cycles in hydrocarbon concentrations at this site.

The measurements indicate that $\mathrm{C}_{2}-\mathrm{C}_{5}$ hydrocarbons are efficiently mixed from the European continent into the Arctic atmosphere during winter. This causes a gradual build-up which in late winter peaks at a sum of $\mathrm{C}_{2}-\mathrm{C}_{5}$ hydrocarbons of around $20 \mathrm{ppbC}$ at $79^{\circ} \mathrm{N}$ on the Zeppelin Mountain, Spitsbergen, close to the average winter concentration at Birkenes, Southern Norway $\left(58^{\circ} \mathrm{N}\right)$. The seasonal cycles in the sum of $\mathrm{C}_{2}-\mathrm{C}_{5}$ hydrocarbons vary significantly among the sites, but most of these differences were due to compounds emitted by combustion (acetylene, ethene and propene). Components related to emissions of natural gas and fuel evaporation were well mixed from central Europe to the Arctic in winter. The higher concentrations of combustion products in Central Europe than at the other stations may indicate an influence from local sources, but could also suggest that traffic emissions in general contain a larger share of combustion compounds than evaporative compounds in winter compared to in summer.

The elevated concentrations at Tänikon, with peaks in the morning and afternoon of most components, show that this site is influenced by local traffic emissions. However, the EMEP grab sampling is performed around noon, when the local influence is lower. In view of the fact that it is practically impossible to find sites in 
densely populated areas with no local VOC sources, methods should be developed to allow for correction of local influences.

The carbonyl measurements indicate that formaldehyde, acetaldehyde and acetone are the three dominant components, and constitute $85 \%$ or more of the total sum of carbonyls which were detected. The seasonal cycles of the carbonyl compounds are mostly opposite to the hydrocarbons, and show a maximum in spring and summer. This is most pronounced for acetone, while acetaldehyde only shows a minor variation during the year. The concentration of several carbonyls were much more abundant at two Italian sites than further north, and the seasonal cycles were quite different. It is not clear, however, whether this is due to a local anthropogenic influence at the sites, or if it is representative of a larger region.

In summer the carbon sum of carbonyls were of the same magnitude as the carbon sum of $\mathrm{C}_{2}-\mathrm{C}_{5}$ hydrocarbons. The seasonal cycle in the percentage amount of carbonyls to the total sum of all VOC (hydrocarbons + carbonyls) were similar at all the sites, from the Zeppelin Mountain in the Arctic to Central Europe. More measurements are needed to clarify if this is a general fact.

\section{Acknowledgements}

The measurements at Tänikon are financed by the Swiss Federal Office of Environment. The authors are grateful for the wind speed data for Tänikon, kindly provided by the Swiss Meteorological Institute (SMA). We also would like to thank Johannes Hov and Liv Aanesland for their work with chromatograms and data handling. Without their effort it would not have been possible to present these recent measurements. Finally, many thanks to all those who were involved in the sampling and shipment of canisters and DNPH tubes.

\section{References}

ATAL, 1994: Luft-Schadstoffe im Kanton Zürich. Immissions-Messbericht 1994, Zürich, Amt für technische Anlagen und Lufthygiene des Kantons Zürich.

Atkinson, R., 1990: Gas-phase tropospheric chemistry of organic compounds: A review, Atmos. Environ. 24A, 1-41.

Atkinson, R., Bauch, D. L., Cox, R. A., Hampson Jr., R. F., Kerr, J. A. and Troe, J., 1992: Evaluated kinetic and photochemical data for atmospheric chemistry: Supplement IV, Atmos. Environ. 26, 1187-1230.

Bailey, J. C., Schmidt, B., and Williams, M. C., 1990: Speciated hydrocarbon emissions from vehicles operated over the normal speed range on the road, Atmos. Environ. 24A 43-52.

Berge, E., Styve, H., and Simpson, D., 1995: Status of the emission data at MSC-W, Oslo, Norwegian Meteorological Institute (EMEP/MSC-W Report 2/95).

Berntsen, T. and Isaksen, I. S. A., 1994: A 3-dimensional photochemistry/ transport model of the global troposphere, Oslo, Inst. for Geophysics, University of Oslo (Institute report no. 89).

Chatfield, R. B., Gardner, E. P., and Calvert, J. G., 1987: Sources and sinks of acetone in the troposphere: Behavior of reactive hydrocarbons and a stable product, J. Geophys. Res. 92, 42084216.

Crutzen, P. J., 1988: Tropospheric ozone: An overview, in I. S. A. Isaksen (ed.), Tropospheric Ozone. Regional and Global Scale Interactions, (NATO ASI series. Series C, Mathematical and physical sciences, 227), Reidel, Dordrecht, pp. 3-32. 
De Saeger, E. and Tsani-Bazaca, E., 1992: EC intercomparison of VOC measurements, Ispra, Joint Research Centre, Environmental Institute.

De Saeger, E., 1994: Second EU intercomparison exercise for VOC measurements. Preliminary results, Ispra, Joint Research Centre, Environmental Institute.

EMEP/CCC, 1995: Manual for sampling and chemical analysis. Kjeller, Norwegian Institute for Air Research (EMEP/CCC-Report 1/95).

Harley, R. A., Hannigan, M. P., and Cass, G. R., 1992: Respeciation of organic gas emissions and the detection of excess unburned gasoline in the atmosphere, Environ. Sci. Technol. 26, 2395-2408.

Haszpra, L., Szilágyi, I., Demeter, A., Turányi, T., and Bérces, T., 1991: Non-methane hydrocarbon and aldehyde measurements in Budapest, Hungary, Atmos. Environ. 25A, 2103-2110.

Hov, Ø., Penkett, S. A., Isaksen, I. S. A., and Semb, A., 1984: Organic gases in the Norwegian Arctic, Geophys. Res. Letters 11, 425-428.

Hov, $\varnothing$., Schmidbauer, N., and Oehme, M., 1989: Light hydrocarbons in the Norwegian Arctic, Atmos. Environ. 23, 2471-2482.

Hov, Ø., Schmidbauer, N., and Oehme, M., 1990: Light hydrocarbons in the Norwegian Arctic. Discussion, Atmos. Environ. 24A, 2889-2890.

Hov, Ø., Schmidbauer, N., and Oehme, M., 1991: $C_{2}-C_{5}$ hydrocarbons in rural south Norway, Atmos. Environ. 25A, 1981-1999.

Hov, Ø. and Schmidbauer, N., 1992: Atmospheric concentrations of nonmethane hydrocarbons at a north European coastal site, J. Atmos. Chem. 14, 515-526.

Hov, Ø., Flatøy, F., Krognes, T., Schmidbauer, N., Heidam, N.Z., Manscher, O. H., Lättilä, H., Areskoug, H., Ferm, M., and Lindskog, A., 1995: The relationship between ozone, peroxyacetylnitrate and precursors in long range transport of photooxidants to Scandinavia, submitted to Atmos. Environ.

Isaksen, I. S. A., Hov, Ø., Penkett, S. A., and Semb, A., 1985: Model analyses of measured concentrations of organic gases in the Norwegian Arctic, J. Atmos. Chem 3, 3-27.

Isaksen, I. S. A., 1988: Is the oxidising capacity of the atmosphere changing? in: F. S. Rowland and I. S. A. Isaksen (eds.), Dahlem Workshop on the Changing Atmosphere. Berlin, 1987, Wiley, Chichester, pp. 141-157.

Iversen, T., 1989: Some statistical properties of ground level air pollution at Norwegian arctic stations and their relation to large scale atmospheric flow systems, Atmos. Environ. 23, 2451-2462.

Lindskog, A., Solberg, S., Roemer, M., Klemp, D., Sladkovic, R., Boudries, H., Dutot, A., Hakola, H., Schmitt, R., Areskoug, H., 1995: The distribution of NMHC in Europe: Results from the Eurotrac TOR project, Abstract from the conference Acid Reign '95, Gothenburg, Water, Air Soil Poll. 85, 2027-2032.

Lowe, D. C. and Schmidt, U., 1983: Formaldehyde (HCHO) measurements in the nonurban atmosphere, J. Geophys. Res. 88, 10,884-10,858.

Lövblad, G., Hjellbrekke, A.-G., Sjöberg, K., Skjelmoen, J, E., and Schaug, J., 1995: Data Report 1993 - Part 2: Monthly and seasonal summaries, Kjeller, Norwegian Institute for Air Research (EMEP/CCC-Report 8/95).

Partridge, R. H., 1992: Assessment of the measurement accuracy of laboratories carrying out VOC determinations in the EC. Preparation of multicarbon mixtures, in E. De Saeger and E. TsaniBazaca (eds.), EC intercomparison of VOC measurements, Ispra, Joint Research Centre Environment Institute, Appendix 1.

Pleil, J. D. and Oliver, K. D., 1987: Enhanced performance of nafion dryers in removing water from air samples prior to gas chromatographic analysis, J. Air Pollut. Control. Assoc. 37, 244-248.

Ratte, M., Plass-Dölmer, C., Koppmann, R., and Rudolph, J., 1993: Production mechanism of $\mathrm{C}_{2}-\mathrm{C}_{4}$ hydrocarbons in seawater: Field measurements and experiments, Global Biogeochem. Cycles 7, 369-378.

Romero, R., 1995: The first laboratory intercomparison of light hydrocarbons in EMEP, Kjeller, Norwegian Institute for Air Research (EMEP/CCC-Report 2/95).

Rudolph, J., Plass-Dölmer, C., Ratte, M., and Koppmann, R., 1993: Investigation of the maritime emissions of reactive light hydrocarbons, in Eurotrac annual report 1992 - Part 3: Air-Sea Exchange (ASE), Garmisch-Partenkirchen, Eurotrac International Scientific Secretariat, pp. 124 127. 
Schmidbauer, N. and Oehme, M., 1986: Improvement of a cryogenic preconcentration unit for $\mathrm{C}_{2}-\mathrm{C}_{5}$ hydrocarbons in ambient air at ppt levels, J. High Res. Chromatogr. \& Chromatogr. Comm. 9, 502-505.

Shepson, P. B., Hastie, D. R., Schiff, H. I., Polizzi, M., Bottenheim, J. W., Anlauf, K., Mackay, G. I., and Karecki, D. R., 1991: Atmospheric concentrations and temporal variations of $C_{1}-C_{3}$ carbonyl compounds at two rural sites in Central Ontario, Atmos. Environ. 25A, 2001--2015.

Singh, H. B., O'Hara, D., Herlth, D., Sachse, W., Blake, D. R., Bradshaw, J. D., Kanakidou, M., and Crutzen, P. J., 1994: Acetone in the atmosphere: Distribution, sources, and sinks, J. Geophys. Res. 99D, 1805-1819.

Slemr, J., 1991: Determination of volatile carbonyl compounds in clean air, Fresenius J. Anal. Chem. 340, 672-677.

Solberg, S., Schmidbauer, N., Dye, C., Pedersen, U., and Schaug, J., 1993: VOC measurements August 1992-June 1993, Lillestrøm, Norwegian Institute for Air Research (EMEP/CCC-Report 6/93).

Solberg, S., Dye, C., and Schmidbauer, N., 1994: VOC measurements 1993, Kjeller, Norwegian Institute for Air Research (EMEP/CCC-Report 3/94).

Solberg, S., Dye, C., Schmidbauer, N., and Simpson, D., 1995a: Evaluation of the VOC measurement programme within EMEP, Lillestrøm, Norwegian Institute for Air Research (EMEP/CCC-Report $5 / 95)$.

Solberg, S., Schmidbauer, N., Stordal, F., and Hov, $\varnothing, 1995$ b: Non-methane hydrocarbons at Birkenes in South Norway, 1988-1993, submitted to Atmos. Environ.

Strand, A. and Hov, $\varnothing, 1994$ : A two-dimensional global study of tropospheric ozone production, $J$. Geophys. Res. 99, 22,877-22,895.

Volz-Thomas, A., Buers, H. J., Flocke, F., Geiss, H., Gilge, S., Heil, T., Houben, N., Klemp, D., Kramp, F., Mihelcic, D., Müsgen, P., Pätz, H. W., Schultz, M., Su, Y., and Kley, D., 1993: Photooxidants and precursors at Schauinsland, Black Forest: Results from continuous measurements of VOCs and organic nitrates. A contribution to EUROTRAC - Subproject TOR, in Eurotrac Annual Report 1992 - Part 9: TOR - Tropospheric Ozone Research, Garmisch-Partenkirchen, Eurotrac International Scientific Secretariat. pp. 147-156.

Warneck, P., 1988: Chemistry of the natural atmosphere, San Diego, Academic Press (International Geophysics Series, 41).

Wirtz, K., Roehl, C., Hayman, D., Jenkin, M. E., and LACTOZ Steering Group, 1994: LACTOZ reevaluation of the EMEP MSC-W photo-oxidant model, Garmisch-Partenkirchen (EUROTRAC special publication). 